\title{
Climate Change, Federalism, And the CONSTITUTION
}

\author{
Daniel A. Farber ${ }^{*}$
}

Federal climate change legislation seems increasingly likely, but at least some states are likely to continue pursuing independent initiatives. Courts, state governments, and EPA will then be faced with the question of how much room remains for state climate regulations. This Article argues for a bifurcated approach to the constitutional authority of states to pursue climate change mitigation. Courts should reject regulations that violate clear statutory preemption clauses, discriminate against interstate commerce, ban transactions under federal cap-and-trade schemes, or directly interfere with international agreements. In the remaining cases, this Article advocates adoption of a strong presumption of validity for state climate change regulation.

\section{INTRODUCTION}

Climate change is a global problem, and there is little doubt about its seriousness and the challenges it poses for our society. As the Intergovernmental Panel on Climate Change's (IPCC) 2007 report explains, scientists agree that concentrations of greenhouse gases (GHGs) "now far exceed pre-industrial values." Moreover, climate change is already upon us. Its effects are already

* Sho Sato Professor of Law and Faculty Director of the California Center for Environmental Law and Policy, University of California, Berkeley. This Article appears in Volume 50 Number 3 of the Arizona Law Review, which collects papers originally presented at the William $\mathrm{H}$. Rehnquist Center on the Constitutional Structures of Government Conference: Federalism and Climate Change: The Role of the States in a Future Federal Regime, hosted in Tucson, Arizona on February 11, 2008. I would like to thank Ann Carlson and Alice Kaswan for helpful comments on an earlier draft, as well as participants at the Rehnquist Center's Conference on Federalism and Climate Change.

1. Intergovernmental Panel on Climate Change, Contribution of Working Group 1 to the Fourth Assessment Report of the Intergovernmental Panel on Climate Change (IPCC), Summary for Policy Makers, Climate Change 2007: The Physical Science Basis, 2 (2007), available at http://www.pnud.cl/recientes/IPCC-Report.pdf [hereinafter IPCC Summary]. The IPCC explains that " $[\mathrm{t}]$ he understanding of anthropogenic warming and cooling influences on climate has improved since the Third Assessment Report (TAR), leading to very high confidence that the globally averaged net effect of human activities since 1750 has been one of warming, with a radiative forcing of $+1.6[+0.6$ to +2.4$] \mathrm{W} \mathrm{m}^{-2}$." Id. at 3 . In ordinary English, this means that human activities have added about one and a 
apparent, ${ }^{2}$ and further impacts are inevitable. ${ }^{3}$ Yet, despite these nearly undeniable facts, the federal government has shown little initiative in addressing this serious issue. $^{4}$

Perhaps surprisingly, ${ }^{5}$ state governments have moved much more aggressively. ${ }^{6}$ By 2006 , every state had taken steps of some kind to address

half watts per square meter of energy to the climate system, or, put another way, roughly the amount of energy that would be added if you divided the earth into 40' $x 40$ ' squares and put a hundred watt light bulb in the middle of each of them. Each individual bulb is not adding that much, but the surface of the earth is very large, so the total amount of energy adds up.

2. "Examples of observed changes caused by human releases of GHG include shrinkage of glaciers, thawing of permafrost, later freezing and earlier break-up of ice on rivers and lakes," as well as biological changes such as "shifts of plants and animal ranges, declines of some plant and animal populations, and earlier flowering of trees, emerging of insects, and egg-laying in birds." Donald A. Brown, The U.S. Performance in Achieving Its 1992 Earth Summit Global Warming Commitments, [2002] 32 Envtl. L. Rep. (Envtl. Law Inst.) $10,741,10,756$. For further details on climate change effects in the United States, see Camille Parmesan \& Hector Galbraith, Observed impacts of Global Climate CHANGE IN THE U.S. (2004), available at http://www.pewclimate.org/global-warming-indepth/all_reports/observedimpacts/.

3. As Brown explains:

Many scientists and policy makers believe that a doubling of $\mathrm{CO}[2]$ from pre-industrial levels to $560 \mathrm{ppm}$ [part per million] may be unavoidable in the 21 st century. . . Some environmentalists, however, believe it is still possible to stabilize GHG at $450 \mathrm{ppm}$, a level that would limit the temperature increase (in addition to that which has already been caused by human activities) to 1.5 to $2^{\circ} \mathrm{F}$ during the next 100 years. Virtually nobody believes that it is possible to stabilize atmospheric concentrations below $450 \mathrm{ppm}$ and concentrations could continue growing after that if [developing] countries do not implement aggressive reduction strategies, even if the most ambitious proposal currently under consideration were adopted. Even if all nations could have stabilized emissions in the year 2002, the concentrations of GHGs would continue to rise and would approach $500 \mathrm{ppm}$ by the year 2100 . After that, GHG concentrations in the atmosphere would continue to rise for several hundred years before stabilization would be achieved.

Brown, supra note 2, at 26 . Given the near inevitability of at least some additional temperature increases, we can expect further unavoidable impacts.

4. For a discussion of the limited federal role in addressing climate change to date, see John C. Dernbach, U.S. Policy, in Global Climate Change and U.S. Law 61 (Michael B. Gerrard ed., 2007).

5. For speculations about the causes of this state-level response, see J.R. DeShazo \& Jody Freeman, Timing and Form of Federal Regulation: The Case of Climate Change, 155 U. PA. L. REv. 1499, 1516-38 (2007); Kirsten Engel, State and Local Climate Change Initiatives: What Is Motivating State and Local Governments to Address a Global Problem and What Does This Say About Federalism and Environmental Law?, 38 URB. LAW. 1015 (2006). The potential for states to play a renewed role in environmental policy innovation was apparent almost a decade ago. See John P. Dwyer, The Role of State Law in an Era of Federal Preemption: Lessons from Environmental Regulation, 60 LAW \& CONTEMP. PROBS. 203, 226 (1997) ("Over the last generation, state agencies have surpassed federal agencies in resources and often in technical expertise, and many of the most innovative programs now originate in the states."). For more skeptical views of state 
climate change.? California is in the lead with legislation aimed at reducing greenhouse emissions from automobiles and electrical generators, as well as an ambitious mandate to reduce emissions to 1990 levels by the end of the next decade. $^{8}$

Passage of federal climate change legislation seems increasingly likely, but some states will continue to pursue independent climate change measures. Though Congress has the final word on whether states can legislate on all matters within its legislative authority, it often remains silent or speaks ambiguously, as demonstrated in the section on preemption. This is likely true of any forthcoming federal climate legislation: either the statute will not address preemption or, more likely, it will fail to do so explicitly. Courts, state governments, and the Environmental Protection Agency (EPA) will then face the question of how much room remains for state climate regulation.

This Article argues for a bifurcated approach to the constitutional authority of states to pursue climate change mitigation measures. ${ }^{9}$ Courts should reject regulations that discriminate against interstate or foreign commerce or ban otherwise lawful transactions under federal trading schemes. Apart from these clearcut types of invalidity, the Article advocates adoption of a strong presumption of validity for state climate change regulation. That presumption would be overcome if a state law is in direct conflict with a statute or international agreement, or if it is clearly covered by a statutory preemption clause.

regulation as an alternative to federal dominance, see Daniel C. Esty, Revitalizing Environmental Federalism, $95 \mathrm{MICH}$. L. REV. 570 (1996). But it should be noted that Esty calls for a "a multitier regulatory structure capable of mixing and matching decision levels depending on the issue at hand" rather than complete centralization. Id. at 652. See also Jonathan B. Wiener, Think Globally, Act Globally: The Limits of Local Climate Policies, 155 U. PA. L. REV. 1961 (2007).

6. State efforts are described in David Hodas, State Initiatives, in GLOBAL Climate Change and U.S. LAW, supra note 4, at 343; Robert B. McKinstry, Jr., Laboratories for Local Solutions for Global Problems: State, Local, and Private Leadership in Developing Strategies to Mitigate the Causes and Effects of Climate Change, 12 PENN ST. ENVTL. L. REV. 15, 15-16 (2004); Barry Rabe, Race to the Top: The Expanding Role of U.S. State Renewable Portfolio Standards, 7 SustaINABle DeV. L. \& POL'Y 10 (2007); Eleanor Stein, Regional Initiatives to Reduce Greenhouse Gas Emissions, in GLOBAL Climate Change and U.S. LaW, supra note 4, at 315 . Local initiatives will not be considered separately in this Article, but are catalogued in J. Kevin Healy, Local Initiatives, in Global Climate Change AND U.S. LAW, supra note 4, at 421. A survey of state efforts can be found in Pace Law School Center for Environmental Legal Studies, The State Response to Climate Change: 50-State Survey, in Global Climate CHANGE AND U.S. LAW, supra note 4, at 371 [hereinafter Pace Center].

7. Hodas, supra note 6, at 343.

8. Pace Center, supra note 6, at 375.

9. Some of the discussion in this Article is also relevant to state authority to adopt climate adaptation measures, at least some of which might raise similar constitutional problems. The primary focus, however, will be on mitigation. "Mitigation" means reducing GHGs and thereby limiting future climate change; "adaptation" means responding to predicted climate change in order to limit the impact on human society or ecosystems. 
Part I of the Article surveys current state efforts in the arena of climate change and some of the federalism issues that have already arisen. ${ }^{10}$ These activities cover a wide spectrum of policy options, and differ greatly in their scope and ambition. Some state activities may fade after Congress enters the field, but states may wish to move faster than Congress or to address sources of GHGs (or types of greenhouse sinks) that Congress has not yet regulated.

Parts II and III of the Article are heavily doctrinal. Part II examines the application of the dormant Commerce Clause to state climate legislation. Part III examines preemption doctrine, finding that state regulation has a good chance of surviving a preemption challenge if it avoids the most obvious constitutional pitfalls, including: discriminating against interstate commerce; banning or burdening behavior explicitly authorized by federal law; taking steps with foreign countries that directly contradict presidential or congressional initiatives; or attaching penalties to transactions that occur wholly outside state borders. But the state initiatives that survive those hurdles will be judged under doctrines such as the Pike balancing test for undue burdens on commerce," "obstacle" preemption based on federal statutes, ${ }^{12}$ and implied foreign affairs preemption, ${ }^{13}$ which are vague and provide little basis for confidence about outcomes. Where these doctrines arguably apply, the Supreme Court has failed to provide clear guidance to states about the extent of their regulatory authority. ${ }^{14}$ There are strong arguments, however, for giving state climate change regulations the benefit of the doubt when applying these amorphous standards.

Part IV considers how climate change might affect our thinking about the constitutional dimension of federalism, including our understanding of federal legislative authority. The creation of new markets under the guise of cap-and-trade schemes will make it even more difficult to draw lines around federal jurisdiction over interstate commerce. These markets, as well as the global web of interactions that result in climate change, will also make problematic the distinctions between local, national, and global concerns. In the meantime, problems like climate change involve a tremendous range of scales from global atmospheric concentrations and temperature effects, on the one hand, to local driving patterns and eroding local beaches, on the other. Such issues cannot be captured by terms such as "local" or "international." In short, the basic concepts of territoriality that underlie much of our federalism jurisprudence are being slowly washed away.

Given the difficulty of pigeonholing climate issues within conventional categories, courts should not be quick to invalidate state climate regulations, regardless of whether Congress has legislated. Society is more likely to respond timidly to climate change; any fear of over-regulation by states would be largely misplaced. The courts should content themselves with policing against the most

10. For earlier discussion of the constitutional issues, see Stein, supra note 6 , at 333-37.

11. Pike v. Bruce Church, Inc., 397 U.S. 137, 142-43 (1970).

12. See Pac. Gas and Elec. Co. v. State Energy Res. Conservation \& Dev. Comm'n, 461 U.S. 190, 226 (1983).

13. See Zschernig v. Miller, 389 U.S. 429, 432 (1968).

14. See infra Parts II, III. 
obvious potential flaws in state legislation and, if there are more subtle flaws, Congress can address them in subsequent legislation.

\section{I. "While Congress SlePt": STATE Climate Initiatives}

In considering the role of the states in regulating climate change, it is important to keep in mind the large contributions by some states to overall GHG emissions, as well as the varied emission trajectories of the states. Between 1990 and 2001 , the state with the largest percentage of emissions, Texas, increased its emissions by $178 \%$ while California, comprising the second largest percentage of emissions, increased by $85 \%{ }^{15}$ Florida, although only fifth on the list, showed a $347 \%$ increase; New York, with a similar level of emissions, actually showed a slight decrease. ${ }^{16}$ There is plenty of room for further progress. American states rank among the least efficient energy users in the world, such as Qatar. ${ }^{17}$ The good news is that there seems to be a lot of low-hanging fruit. If U.S. per capita emissions were the same as California's per capita emissions, total U.S. emissions would be nearly cut in half. ${ }^{18}$

State efforts to address climate change focus on two key sectors: electrical power and transportation, each lending itself to a different regulatory approach. Power generation and distribution are industrial activities regulated through public utility laws and have relatively few large-scale emission sources. Within the transportation sector, there are fuels of varying carbon intensities, and efforts will be made to encourage the use of gasoline substitutes such as biofuels or the use of non-internal combustion engines. Despite these options, the consumers who comprise the majority of the U.S. transportation industry have access, predominantly, to gasoline. The absence of alternatives makes carbon emissions inevitable at least in the near- to medium-terms. Hence, regulations are more likely to focus on reducing gasoline use than on fuel-shifting.

\section{A. Regulation of Electricity Supply and Demand}

There are essentially four ways to reduce carbon emissions from electrical generation: (1) switching fuels at existing plants to those with a higher energy content (and hence lower emissions per unit of electricity generated), for instance, converting from the use of coal to natural gas; (2) increasing the share of electricity from existing renewable sources, as compared with the share produced from fossil fuels; (3) increasing the construction of carbon-neutral generating facilities while restricting fossil fuel generators; or (4) decreasing the total amount of electricity produced through demand-side conservation measures. States have used varying combinations of these techniques to reduce emissions. The result is an abundance of loosely related initiatives that are difficult to describe in a coherent way. This section will merely touch upon some of the state initiatives.

15. Michael B. Gerrard, Introduction, in Global Climate Change and U.S. LAW, supra note 15 , at 10 .

16. Id.

17. Hodas, supra note 6 , at 345 .

18. Id. at 346. Of course, California enjoys a milder climate than other states and may have other advantages that would preclude other states from matching its performance. 
Renewable portfolio standards (RPSs), which require that a certain percentage of retail electricity sales be derived from renewable sources, are an important option for state regulators. The programs are quite diverse in their ambition and effectiveness. ${ }^{19}$ California's program has an especially ambitious $33 \%$ target for renewables by $20200^{20} \mathrm{~A}$ similar effort involves public benefit funds that apply a surcharge to consumer utility bills in order to generate funding for investment in clean energy sources. ${ }^{21}$

Some of the most interesting initiatives are regional rather than statebased. $^{22}$ Regional programs include the well-known Northeast Regional Greenhouse Gas Initiative (RGGI), as well as initiatives in New England, the Great Plains, the Southwest, and along the West Coast. ${ }^{23}$ Regional cooperation is feasible because two-thirds of Americans receive their power from regional transmission organizations or independent system operators. ${ }^{24}$ Coverage is incomplete, however; five companies are virtually outside these regional agreements, yet account for a quarter of the American electricity sector's emissions. ${ }^{25}$ Approximately half of the states are involved in at least one regional initiative. ${ }^{26}$

RGGI is the most noteworthy of these regional plans. Maryland's legislature and governors in Connecticut, Delaware, Maine, New Hampshire, New Jersey, New York, and Vermont currently support it, ${ }^{27}$ and the Governor of California has announced plans to become a trading partner of RGGI. ${ }^{28}$ It aims to create a multistate trading system, by capping emissions at current levels from 2009 until 2015 and then achieving a $10 \%$ reduction by $2019 .{ }^{29}$ Allowances will be initially allocated to generators on the basis of current emissions, but sources will also be allowed to offset emissions to a limited extent with verifiable reductions in other emission sources. ${ }^{30}$ One continuing concern, however, is leakage: that the

19. Gerrard, supra note 4, at 22 .

20. Hodas, supra note 6 , at 356 . Hodas provides a list of sources considered renewable by various states. The outliers are Minnesota, which includes only wind and biomass, and Rhode Island and Colorado, the only states to include small hydroelectric facilities. Three states also include energy efficiency as a "renewable source." Id. Another interesting effort to encourage clean energy investment involves the use of carbon adders, which require utility companies to forecast future costs relating to climate change externalities and regulation as part of their costing of new facilities. Id. at 360-62. Rabe, supra note 6 , contains a more detailed appraisal of renewable portfolio standards.

21. Hodas, supra note 6, at 359.

22. See Kirsten H. Engel, Mitigating Global Climate Change in the United States: A Regional Approach, 14 N.Y.U. ENVTL. L.J. 54 passim (2005).

23. Stein, supra note 6 , at 316 . For more on systems other than RGGI, see $i d$. at 326-31. For further progress on the Western state initiative, see Tom Alkerie, Western Climate Initiative to Finalize Design for Emissions Trading Scheme by August, 31 Int'l Env't Rep. (BNA) No. 2, at 65 (Jan. 23, 2008).

24. Stein, supra note 6 , at 317.

25. Id. at 318.

26. Hodas, supra note 6, at 347.

27. Stein, supra note 6, at 321.

28. Id.

29. Id.

30. Id. at 324-25. 
system will not result in reduced net emissions because utilities will avoid the higher costs of compliance through the purchase of cheaper electricity from higher emitting sources outside of the trading area. ${ }^{31}$

The most ambitious trading system is likely to be established under California's A.B. 32. A.B. 32 requires California to reduce emissions to the 1990 level by 2020 and allows, but does not mandate, the use of a trading system to do so. ${ }^{32}$ This law generated worldwide attention when it was passed, including a statement by British Prime Minister Tony Blair that its signing represented a "historic day for the ... world ...."33 The Prime Minister and the Governor of California also entered an agreement to share best practices on market-based systems and to cooperate to investigate new technologies. Similar agreements now exist between California and states and provinces in Australia and Canada. ${ }^{34}$ Although A.B. 32 does not mandate the use of cap-and-trade, there are strong arguments for using this mechanism. ${ }^{35}$

Another prong of state regulation has been the development of efficiency standards for electrical appliances. State appliance standards are normally subject to federal preemption, but the Department of Energy (DOE) has proposed waiving preemption so that states can provide for higher energy conservation standards than are federally mandated. At least ten states have set such standards, benefiting consumers in the process. ${ }^{36}$ California estimates that by 2020 its standards will have saved consumers three billion dollars in utility bills for power that would otherwise have been consumed and that it will eliminate the need for three new power plants. ${ }^{37}$

Electricity regulation can produce significant federalism issues, which state regulators clearly need to address. ${ }^{38}$ The primary problem is leakage:

31. Id. at 322-23. A related concern is shifting; that is, the possibility that California utilities will switch to less carbon intensive out-of-state sources (avoiding the leakage problem) but that the more intensive sources will simply be freed up to sell their power elsewhere in the nation.

32. Erwin Chemerinsky et al., California, Climate Change, and the Constitution, [2007] 37 Envtl. L. Rep. (Envtl. Law Inst.) 10,653, 10,653.

33. Id. at 10,654 .

34. Id. at 10,659 . The question of whether agreements of this kind are valid is analyzed in Hannah Chang, Foreign Affairs Federalism: The Legality of California's Link With the European Union Emissions Trading Scheme, [2007] 37 Envtl. L. Rep. (Envtl. Law Inst.) 10,771 passim.

35. See Lawrence H. Goulder, California's Bold New Climate Policy, 4 ECONOMISTS' VOICE, Sept. 2007, http://www.bepress.com/ev/vol4/iss3/art5. A cap-andtrade system sets a cap on the total emissions of some pollutants, allocates pollution rights to individual sources that, in the aggregate, correspond to the cap, and then allows the sources to trade pollution rights among themselves.

36. Hodas, supra note 6, at 364 .

37. Id.

38. For an overview of these federalism issues, see Kirsten $\mathrm{H}$. Engel, The Dormant Commerce Clause Threat to Market-Based Environmental Regulation: The Case of Electricity Deregulation, 26 ECOLOGY L.Q. 243 (1999). Engel argues that:

[B]arriers to interstate commerce should be considered constitutionally

permissible when they result from state efforts to (1) retain the benefits 
reducing in-state emissions may simply result in shifting supply to unregulated out-of-state sources. ${ }^{39}$ In adopting utility regulation for GHGs, the California Public Utility Commission (PUC) has been very conscious of potential federalism issues. The standards do not directly regulate out-of-state sources. Instead, they govern the contracts that can be used by in-state utilities with sources of electricity. According to the PUC, the purpose of the standards is in part to cushion California retail power users from the costs that might result from later imposition of federal standards on generators that are unprepared to meet them. ${ }^{40}$

The PUC's Interim Opinion on Phase 1 Issues: Greenhouse Gas Emissions Performance Standards discusses an array of potential legal objections to the standards. ${ }^{41}$ The rulemaking involves environmental performance standards for long-term supply contracts entered into by California power systems. The standards are based on the theory that future regulations by the federal government or the state where the generator is located could result in reduced operations of existing generators or reduced expansion of facilities to meet future needs in other states, reducing the amount of electricity available to California consumers. Such future regulations might also require expensive retrofits of generating facilities to meet later regulatory requirements, the cost of which would be incurred by consumers. Much of California's electricity comes from out-of-state. Only those out-of-state generators that meet the environmental performance standards will be able to enter into long-term contracts to sell electricity in the state, which could impose higher costs due to the investments required to meet the standards.

Opponents of the rule raise several preemption arguments. They suggest that the California rule conflicts with a presidential policy of avoiding unilateral reductions in U.S. carbon dioxide emissions in favor of multilateral agreements that would include developing nations. The PUC believed, however, that the U.S. foreign policy was in fact a refusal to enter into multilateral agreements that lacked binding restrictions on developing countries. The PUC considered it "unclear how

of an incentive-based environmental market the state itself has created; (2) prevent the loss, to other jurisdictions, of the benefits generated where citizens collectively invest in industries using more environmentally sensitive production processes; or (3) stem the flow, to other states, of conventional economic benefits that result when a state forces industries to internalize the environmental costs of production and waste disposal.

Id. at 250 .

39. The general issue of leakage is discussed in Wiener, supra note 5, at 196774.

40. For a detailed discussion of the preemption issues, see Patricia Weisselberg, Comment, Shaping the Energy Future in the American West: Can California Curb Greenhouse Gas Emissions from Out-of-State, Coal-Fired Power Plants Without Violating the Dormant Commerce Clause?, 42 U.S.F. L. REv. 185 (2008).

41. Order Instituting Rulemaking to Implement the Commission's Procurement Incentive Framework and to Examine the Integration of Greenhouse Gas Emissions Standards into Procurement Policies, Decision 07-01-039 passim (January 25, 2007), available at http://docs.cpuc.ca.gov/word_pdf/FINAL_DECISION/64072.pdf [hereinafter PUC Order]. 
California, which is not proposing to sign any international agreement here, could be undermining such a policy." ${ }^{, 42}$

Opponents also claim that the proposed rule is preempted by various federal statutes. ${ }^{43}$ In particular, they contend that the rule could interfere with the federal government's exclusive jurisdiction over electricity wholesalers. But the federal government does not regulate retail electrical firms, and the proposed regulation applied only to retail firms (though it did limit their contracts with some generators via wholesalers).

Finally, opponents argue that the regulation violates the dormant Commerce Clause. ${ }^{44}$ The PUC rejects the claim that the rule would have a discriminatory effect on out-of-state coal-fuel generation plants. In the PUC's view, this claim fails because the rule "does not discriminate based on geographic origin." ${ }^{, 45}$ Moreover, the regulation does not unduly burden interstate commerce. It had substantial local benefits because of the potential harm to California from climate change and the "potential exposure of California customers to future reliability problems in electricity supplies. ${ }^{, 46}$ The burden on some out-of-state producers-mostly those in the Southwest, because hydropower producers in the Northwest would be unaffected ${ }^{47}$ - was incidental and not clearly excessive compared with the environmental benefits, at least in the PUC's view. ${ }^{48}$ The PUC's ruling is likely to be the starting point for protracted debate and litigation on the subject.

\section{B. Transportation Regulation}

The transportation sector is a critical part of climate change regulation. California again has taken the lead. Beginning with the 2009 model year, the California Air Resources Board (CARB) has a mandate to reduce $\mathrm{CO}_{2}$ emissions from new car models by $30 \%$ on a fleet average basis. ${ }^{49}$ A statute known as A.B.

42. Id. at 193. For further discussion of the foreign affairs preemption issue in connection with climate change, see Chemerinsky et al., supra note 32 , at $10,662-64$, as well as text accompanying notes to Part III, infra.

43. PUC Order, supra note 41 , at 199.

44. Id. at 206.

45. Id. at 207.

46. Id. at 213 .

47. Id. at $217-18$.

48. Id. at 220. See also Peter Carl Nordberg, Note, Excuse Me, Sir, But Your Climate's on Fire: California's S.B. 1368 and the Dormant Commerce Clause, 82 NotRE DAME L. REV. 2,067 (2007) (similar analysis of dormant Commerce Clause issues); Margaret Tortorella, Will the Commerce Clause "Pull the Plug" on Minnesota's Quantification of the Environmental Externalities of Electricity Production?, 79 MINN. L. REV. 1547 (1995) (defending constitutionality of Minnesota law favoring utility contracts with renewable sources). An alternative to the California scheme would be for the state to act as the exclusive purchasing agent for electricity, thereby taking advantage of the "market participant exception" discussed later in this Article. See Brian H. Potts, Regulating Greenhouse Gas "Leakage": How California Can Evade the Impending Constitutional Attacks, ELECTRICITY J., June 2006, at 43.

49. Kirsten H. Engel \& Scott R. Saleska, Subglobal Regulation of the Global Commons: The Case of Climate Change, 32 Ecology L.Q. 183, 221 (2005). The statutory 
1493 directs the California Air Resources Board to adopt regulations that achieve "the maximum feasible and cost-effective reduction of greenhouse gas emissions from motor vehicles." The CARB may not, however, impose fees or taxes, ban SUVs or light trucks, or impose speed limits. ${ }^{50}$ California is also moving toward adoption of a low-carbon fuel standard. ${ }^{51}$

Federalism has been a significant issue in terms of vehicle regulation, particularly regarding the new car regulations authorized by A.B. 1493. The state's regulatory scheme has been challenged on several grounds. To begin, the Clean Air Act prohibits any state from adopting regulations concerning emissions from new vehicles. The sole exception is for California, which can be granted a waiver from preemption if EPA determines that the state standards are at least as stringent as the federal standards. EPA contended that carbon dioxide was not an "emission" within the meaning of the statute, generating controversy about the application of the preemption and California waiver provisions. ${ }^{52}$ Those issues have since been resolved, but the statute allows EPA to reject the waiver application on the ground that California had failed to establish the existence of "compelling and extraordinary conditions." 53

California also faces claims that its regulations are preempted by the federal Corporate Average Fuel Economy (CAFE) standards. The statute establishing the federal standards explicitly prohibits states from issuing any regulations that "relate to fuel economy standards." 54 Reducing carbon dioxide emissions from automobiles requires burning less gasoline; the question is whether the CARB can craft regulations that may indirectly have this effect without falling into the realm of regulation forbidden by the CAFE standards. California may take some cheer from Massachusetts v. EPA, ${ }^{55}$ where the federal government used a similar argument in support of its claim that EPA lacked jurisdiction over carbon dioxide under the Clean Air Act. In that case, the Court responded to the government's argument:

EPA finally argues that it cannot regulate carbon dioxide emissions from motor vehicles because doing so would require it to tighten mileage standards, a job (according to EPA) that Congress has assigned to DOT [Department of Transportation]. But that DOT sets mileage standards in no way licenses EPA to shirk its environmental responsibilities. EPA has been charged with protecting the public's "health" and "welfare," a statutory obligation

mandate is A.B. 1493, also called the Pavley Act, which requires the state to issue regulations achieving the "maximum feasible and cost-effective reduction of greenhouse gas emissions" from vehicles. CAL. HEALTH \& SAFETY CODE $\S 43018.5$ (a) (West. 2006).

50. See Ann E. Carlson, Federalism, Preemption, and Greenhouse Gas Emissions, 37 U.C. DAvis L. REV. 281, 292 (2003).

51. See DeShazo and Freeman, supra note 5, at 1527. For the relevant gubernatorial executive order, see Cal. Exec. Order No. S-01-07 (January 18, 2007), available at http://gov.ca.gov/index.php?/print-version/executive-order/5172/.

52. Carlson, supra note 50, at 293-96.

53. Id. at 296-97.

54. Id. at 303.

55. 127 S. Ct 1438 (2007). 
wholly independent of DOT's mandate to promote energy efficiency. The two obligations may overlap, but there is no reason to think the two agencies cannot both administer their obligations and yet avoid inconsistency. ${ }^{56}$

The Court's discussion of the relationship between DOT and EPA does not speak directly to the issue of state preemption, but does suggest that the Court views fuel efficiency rules and limitations on carbon dioxide emissions as two very different matters. 57

The first ruling on the validity of the California program came in Green Mountain Chrysler Plymouth Dodge Jeep v. Crombie (Green Mountain Chrysler). ${ }^{58}$ There, a Vermont district court considered whether the federal agencies involved could work out any tensions between federal fuel economy standards and California's right to a waiver from EPA. ${ }^{59}$ The court held that the GHG regulations encompassed much more than a fuel economy mandate, because the regulations encompassed upstream emissions from refineries and other fuel sources. ${ }^{60}$ The court also held that the challengers had failed to prove that the rules were technologically or economically infeasible. ${ }^{61}$ The court rejected the argument that the California rules improperly intruded into the field of foreign affairs, ${ }^{62}$ noting that the State Department had, in fact, praised state and local efforts in its reports to international agencies. ${ }^{63}$

California's program also passed muster in a separate challenge, Central Valley Chrysler-Jeep, Inc. v. Goldstene (Central Valley). ${ }^{64}$ Relying heavily on Massachusetts v. EPA for guidance about the relationship between the Clean Air Act and CAFE standards, a California district court ruled that if the California standards were approved by EPA, the DOT would have a duty to harmonize the CAFE standards with the California requirements. ${ }^{65}$ The district court also relied on Massachusetts $v$. EPA in concluding that policy promulgated by the executive branch could not override the congressionally mandated standards for California's waiver request. ${ }^{66}$ The district court held that a claim of foreign policy preemption would require a showing that the state law conflicted with an international

56. Id. at 1461-62.

57. The Congressional Research Service concluded that California should qualify for a waiver, particularly in light of Massachusetts v. EPA. See Report Finds California Has Strong Case to Get Approval of Vehicle Emissions Rules, 38 Env't. Rep. (BNA) No. 35 (Sept. 7, 2007). EPA later denied the waiver. See infra text accompanying note 68 .

58. 508 F. Supp. 2d 295 (D. Vt. 2007).

59. Id. at 356 .

60. Id. at 353 .

61. Id. at 357 .

62. Id. at 395.

63. Id. at 396.

64. 529 F. Supp. 2d 1151 (E.D. Cal. 2007).

65. Id. at 1170 .

66. Id. at 1181 . 
agreement or at least a program that derived from international negotiations, neither of which was present. ${ }^{67}$

From the point of view of California and other states that wished to adopt the California standard, Green Mountain Chrysler and Central Valley were promising rulings. Shortly after the latter decision, however, EPA administrators rejected California's waiver request. ${ }^{68}$ The State immediately announced its intention to litigate the refusal. As a result, the implicated federalism issues will not likely find resolution in the near future.

Even if California is unable to adopt across-the-board restrictions on carbon dioxide emissions from vehicles, the state may still be able to do so on a more limited basis. The Ninth Circuit recently upheld a requirement that state and local governments with large vehicle fleets purchase only low-emission vehicles, even though the Supreme Court had previously struck down a similar rule that applied to private buyers. ${ }^{69}$ The rules were not eligible for the California waiver at issue in the case because they were adopted by a regional California authority, rather than the state itself. Other possible regulatory options might include mandates for zero emission vehicles, which could be justified on non climate change grounds because they would reduce emissions of conventional air pollutants, and higher registration fees for large vehicles.

Litigation may also be an affirmative strategy for states seeking to reduce emissions. A recent case filed by the State of California is illustrative. ${ }^{70}$ In an action in federal district court against leading automobile manufacturers, the State alleges two causes of action for public nuisance: one under federal common law ${ }^{71}$

67. Id. at $1186-89$.

68. See EPA, America Receives a National Solution for Vehicle Greenhouse Gas Emissions (Dec. 19, 2007), available at http://yosemite.epa.gov/opa/admpress.nsf/ d0cf6618525a9efb85257359003fb69d/41b4663d8d3807c5852573b6008141e5!OpenDocum ent.

69. Engine Mfrs. Ass'n v. S. Coast Air Quality Mgmt. Dist., 498 F.3d 1031, 1038 (9th Cir. 2007). The court relied on precedent, holding that state proprietary activities are not preempted in the absence of a contrary indication from Congress. Id. at 1041. The court also remarked that "[i]t is possible that some aspects of the [market participant] doctrine have a constitutional dimension, protecting certain sovereign activities of the states from unconstitutional interference by the federal government." Id. at 1042. This seems to be a dubious proposition in light of Garcia v. San Antonio Metro. Transit Auth., 469 U.S. 528 (1985) (holding that states are adequately protected by the political process and enjoy no immunity from non-discriminatory regulation under the commerce clause). The primary issue in Engine Manufacturers was whether the market participant exception applied even though the rule applied to local governments as well as the state government itself. 498 F.3d at 1042. The court's conclusion that the doctrine did apply seems well-founded, since the U.S. Constitution does not speak to the division of authority between state and local governments. See id. at 1050.

70. California v. Gen. Motors Corp., No. C06-05755 MJJ, 2007 WL 2726871 (N.D. Cal. Sept. 17, 2007).

71. See Milwaukee v. Illinois \& Michigan, 451 U.S. 304, 317-18 (1981) (holding that federal common law of interstate nuisances was preempted by the Clean Water Act); Illinois v. Milwaukee, 406 U.S. 91, 100-02 (1972) (applying federal common law to nuisance cases filed by states). 
and one under state law. ${ }^{72}$ The gist of the complaint is that automobiles sold by the defendants contributed to climate change and thereby inflicted harm on the state and its citizens. The complaint focuses on several key examples of damages. For instance, the State allegedly will be required to spend large sums of money on studies and infrastructure changes to its water systems. The Sierra Nevada snow pack, which is the source of much of the state's water, has been shrinking. ${ }^{73}$ This decrease in snow pack is likely to increase flooding and interfere with the state's water system. ${ }^{74}$ The complaint adds that "[a]ll of these impacts are the subject of State study and planning, which costs the State millions of dollars., 75 Consequently, the State requests that the defendants be held jointly and severally liable for monetary damages. ${ }^{76}$ At present, the case is pending on appeal after the district court ruled that the litigation was precluded by the political question doctrine. $^{77}$

The issues discussed in this section offer a sampling of the kinds of actions that states may take in response to the threat of climate change and the

72. Gen. Motors, 2007 WL 2726871, at *2.

73. California derives much of its water from the snow pack. The problem is not so much a decrease in total precipitation, but the fact that the snow pack acts as a natural storage system, releasing water during the spring and summer when it is most necessary for agriculture.

74. Complaint at 2-3, California v. Gen. Motors Corp., No. C06-05755, MJJ 2007 WL 2726871 (N.D. Cal., filed Sept. 30, 2006). The complaint also addresses other alleged harms. $I d$. at 2-3, 9-12. Rising sea levels allegedly cause increased beach erosion and increased salt infiltration into the Sacramento Bay-Delta, which will require increased expenditures on levees. Furthermore, climate change is impacting extreme heat events, increasing the risk of injury or death (especially to the elderly). Id. at 12 . Finally, the complaint alleges that "[d]ozens of other impacts have begun or are anticipated with a high level of certainty, including increased risk and intensity of wildfires, risk of prolonged heat waves, loss of moisture due to earlier snow pack melt and related impacts on forests and other ecosystems, and a change in ocean ecology as water warms." Id.

75. Id. at 12 .

76. Id. at 3. The complaint also requests declaratory relief, as well as attorney fees. Id. Similar litigation against electrical power generators is pending in the Second Circuit. See, e.g., Connecticut v. Am. Elec. Power Co., 406 F. Supp. 2d 265 (S.D.N.Y. 2005). For a detailed discussion of these lawsuits and the place of litigation in the overall effort against climate change, see Alice Kaswan, The Domestic Response to Global Climate Change: What Role for Federal, State, and Litigation Initiatives?, 42 U.S.F. L. REV. 39 (2007).

77. See Gen. Motors, 2007 WL 2726871, at *13. See also Connecticut v. Am. Elec. Power Co., 406 F. Supp. 2d 265 (S.D.N.Y. 2005) (reducing a similar suit against electrical utilities on political-question grounds). On the other hand, a similar public nuisance suit was allowed to go forward in North Carolina v. Tenn. Valley Auth., $439 \mathrm{~F}$. Supp. 2d 486, 494-95 (2006). Reliance on the political question doctrine seems misplaced here, given the narrow scope of that doctrine as defined by the Supreme Court. For further discussion, see Daniel A. Farber, Tort Law in the Era of Climate Change, Hurricane Katrina, and 9/11: Exploring Liability for Extraordinary Risks (April 13, 2008), available at http://ssrn.com/abstract $=1121125$. 
resulting constitutional issues. ${ }^{78}$ Those constitutional issues revolve around the dormant Commerce Clause and federal preemption, which are explored at length in the next two sections.

\section{The Dormant Commerce Clause}

In a unified national economy, the existence of a multitude of differing state environmental laws can impede the flow of commerce, imposing costs not only on consumers in the regulating jurisdiction but on consumers and firms elsewhere. Yet, as illustrated by the climate legislation discussed in Part I, states have often been in the lead in the environmental arena because of the need to address pressing local problems. The tension between the local interest in regulation and the economic interests of other states cannot be resolved effectively by the courts of any of the states involved. Obviously, both the state that is engaging in regulation and the states that are affected by the regulation have interests that disable them from providing a completely neutral forum. Thus, Congress is the ideal forum for resolving these conflicts, but it often cannot attend to these issues because of more pressing legislative concerns. For this reason, the federal courts have emerged as the tribunal for assessing these conflicting interests, applying what is called the dormant Commerce Clause doctrine. This Part will describe the current doctrine generally and then consider its application to state climate change regulations.

\section{A. Doctrinal Overview}

The basis for federal court involvement in scrutinizing state regulations that affect interstate commerce is the Commerce Clause of the Constitution. ${ }^{79}$ The Commerce Clause, on its face, is a grant of power to Congress, not a grant of power to the federal courts or a restriction on state legislation. Yet, from the early Nineteenth Century, the Supreme Court has construed the Commerce Clause as preventing certain kinds of state legislation even when Congress has not spoken ${ }^{80}$ Various theories have been deployed to support judicial intervention, while restrictions have been subject to changing formulations. For present purposes, however, we can ignore the rather tangled history of Commerce Clause theory and concentrate on current doctrine. ${ }^{81}$

78. For an overview of the evolution of federalism issues in environmental law, see Robert V. Percival, Environmental Federalism: Historical Roots and Contemporary Models, 54 MD. L. REV. 1141 (1995).

79. A recent review of the doctrine in relation to state climate change regulation can be found in Chemerinsky et al., supra note 32, at 10,656-59.

80. Early examples include Gibbons v. Ogden, 22 U.S. 1 (1824); Wilson v. Black Bird Creek Marsh Co., 27 U.S. 245, 252 (1829); and Cooley v. Board of Wardens, 53 U.S. 299 (1851). In Cooley, the Court focused on whether there was a need for national uniformity in regulating a particular aspect of some activity (piloting ships into harbor). 53 U.S. at $311-12$.

81. For defenses of the doctrine's legitimacy, see Richard B. Collins, Economic Union as a Constitutional Value, 63 N.Y.U. L. REv. 43 (1988); Daniel A. Farber, State Regulation and the Dormant Commerce Clause, 3 CONST. COMMENT. 395 (1986); Donald H. Regan, The Supreme Court and State Protectionism: Making Sense of the Dormant 
At present, courts apply three tests under the dormant Commerce Clause. One test governs state legislation that discriminates against interstate commerce. Such legislation is virtually per se unconstitutional. A second test applies to the state's proprietary activities. Such activities are virtually immune from restriction under the dormant Commerce Clause. The third test applies to the remaining forms of state legislation. These forms of legislation are covered by a balancing test.

The first test is illustrated by City of Philadelphia $v$. New Jersey. ${ }^{82}$ This case involved a New Jersey statute prohibiting the import of most waste originating outside the state. ${ }^{83}$ The Supreme Court struck down this restriction. ${ }^{84}$ According to the Court, regardless of whether the state's ultimate purpose was economic protectionism or environmental protection, the state could not pursue that goal by treating out-of-state items differently only because of their point of origin, nor could the state solve its problems by isolating itself from the flow of interstate commerce. ${ }^{85}$ As it turned out, Philadelphia v. New Jersey was simply the first in a series of cases in which the Court thwarted efforts by states to control the flow of garbage. One recurrent issue involves the converse of Philadelphia $v$. New Jersey: rather than attempting to exclude garbage imports, the government was trying to ban garbage exports. Many municipalities adopted flow control ordinances that require all waste generated in the locality to be sent to a designated facility. The main reason for the requirement was to assure a sufficient quantity of waste in order to finance expensive state-of-the-art waste disposal facilities.

A divided Court in $C \& A$ Carbone, Inc. v. Town of Clarkstown ${ }^{86}$ found that flow control was facially discriminatory and struck it down under the Philadelphia v. New Jersey test. As Carbone illustrates, what constitutes discrimination is sometimes in the eye of the beholder: what five Justices considered to be patent discrimination, the other four did not find to be

Commerce Clause, 84 MiCH. L. REv. 1091 (1986); Mark Tushnet, Rethinking the Dormant Commerce Clause, 1979 WIS. L. REV. 125 (1979). Although the Supreme Court's recent avowal of the values of federalism might lead one to expect a greater tolerance for state regulation that affects interstate commerce, the Court has not loosened restrictions on state regulation and arguably has tightened them. See Richard H. Fallon, Jr., The "Conservative" Paths of the Rehnquist Court's Federalism Decisions, 69 U. CHI. L. REV. 429, 460-61 (2002). As Fallon explains:

[A] Court minded to pare back restrictions as a means of empowering state and local governments could easily do so - for example, by establishing that only expressly discriminatory taxes and tariff-like devices are forbidden. Among the most plausible explanations for the Court's failure to do so, despite the frequent dissenting protests of Justices Scalia and Thomas, is that the substantive conservatism of Justice O'Connor and Kennedy draws them to view the Commerce Clause as embodying antiregulatory, procompetitive ideals.

Id. at $470-71$.

82. 437 U.S. 617 (1978).

83. Id. at $618-19$.

84. Id. at 629 .

85. Id. at $628-29$.

86. 511 U.S. 383 (1994). 
discriminatory at all. ${ }^{87}$ The majority pointed to several alternatives to flow control, including the use of property taxes to subsidize the local disposal facility ${ }^{88}$ Justice O'Connor concurred in the result. ${ }^{89}$ She considered the ordinance to be nondiscriminatory but struck it down as an undue burden on commerce under the balancing test discussed below. ${ }^{90}$ Applying the same balancing test, Justice Souter and two other dissenters would have upheld the local ordinance. ${ }^{91}$

Under Philadelphia v. New Jersey, state efforts to control the flow of goods across state lines are highly suspect. ${ }^{92}$ Thus, it is critical for climate change measures to be neutral as between local and out-of-state sellers and buyers. Since climate change effects are unrelated to the location of the activity, there is little justification for discrimination as a policy matter, even apart from constitutional constraints. State regulators are certainly aware of these rules, as shown by the effort to cast California's standards for electrical power contracts in nondiscriminatory terms.

The second test applies to proprietary or quasi-proprietary activities by the state. ${ }^{93}$ Here, the leading case is Hughes v. Alexandria Scrap Corp. ${ }^{94}$ This case involved a Maryland bounty system for old, abandoned cars, which discriminated against out-of-state scrap dealers. ${ }^{95}$ The Court held that this statute was valid, however, because the State was not exercising a regulatory function but rather had itself entered the market in order to bid up prices. ${ }^{96}$ The Court's most recent decision regarding state proprietary activities illustrates how exercises of proprietary authority can be used to avoid the restrictions of Philadelphia v. New Jersey by moving a case out of the first test. In United Haulers Ass'n, Inc. $v$. Oneida-Herkimer Solid Waste Mgmt. Auth. (United Haulers), ${ }^{97}$ a city ordinance required all local waste haulers to bring their waste to a city-owned facility. The Court found this distinction from Carbone (where the facility had been privately owned) to be critical. ${ }^{98}$

87. Id.

88. Id. at 384

89. Id. at 410 .

90. Id. at 404-06.

91. Id. at $422-30$.

92. See 437 U.S. 617, 623-24 (1978).

93. For discussion of this issue, see Dan T. Coenen, Untangling the MarketParticipant Exemption to the Dormant Commerce Clause, 88 MiCH. L. REV. 395 (1989); Mark P. Gerger, The Selfish State and the Market, 66 TEX. L. REv. 1097 (1988).

94. 426 U.S. 794 (1976).

95. Id. at $799-800$.

96. Id. at 809-10. As Justice Stevens noted in his concurrence, the interstate commerce at issue would never have existed except for the state's bounty system. $I d$. at 815 (Stevens, J., concurring). Because the state's failure to create such commerce would have been unobjectionable under the Commerce Clause, Justice Stevens believed that out-of-state processors had no grounds for complaint if they were excluded from this commerce. Id. at 815-16.

97. 127 S. Ct. 1786 (2007).

98. Id. at $1795-97$. 
Nondiscriminatory state legislation is not as suspect as legislation that is discriminatory on its face. Nevertheless, there is a real risk that the state may pass legislation without adequately considering its impact elsewhere in the country or that apparently neutral legislation is actually designed to favor local businesses. In order to guard against these risks, the Court subjects nondiscriminatory state legislation to a balancing test. Balancing tests are not always predictable in their application, and this one is no exception.

The use of this balancing test has been attacked by Justice Scalia, some lower court judges, and several scholars. ${ }^{99}$ These critics have assembled several arguments against the use of a balancing test to assess nondiscriminatory legislation. If a state law does not discriminate against interstate commerce, they argue, the federal courts should not second-guess the state legislature about the balance between a statute's costs and benefits. ${ }^{100}$ Moreover, ill-advised but nondiscriminatory statutes are subject to a built-in political check, because the adversely affected local industry will lobby for repeal. ${ }^{101}$ Thus, these laws can be handled by the political process without judicial intervention. Finally, these critics argue, the judicial balancing in these cases is unhappily reminiscent of the era in which courts routinely overturned statutes they considered unwise, an approach that has long since been repudiated in other contexts. ${ }^{102}$ Although these arguments against the balancing test have some force, so far they have failed to make much headway in the Court. At the very least, these arguments suggest that only regulations with a disparate impact on out-of-state commerce should be subject to the balancing test, as opposed to regulations that burden interstate commerce but subject local commerce to an equal burden. ${ }^{103}$

The Court's most recent application of this test was the United Haulers case discussed above. The Court held that the benefits of the flow-control regime clearly outweighed any possible burden on interstate commerce:

The ordinances give the Counties a convenient and effective way to finance their integrated package of waste-disposal services. While "revenue generation is not a local interest that can justify discrimination against interstate commerce," . . . we think it is a cognizable benefit for purposes of the Pike test.

At the same time, the ordinances are more than financing tools. They increase recycling in at least two ways, conferring significant health and environmental benefits upon the citizens of the Counties. First, they create enhanced incentives for recycling

99. See CTS Corp. v. Dynamics Corp., 481 U.S. 69, 95-96 (1987) (Scalia, J., concurring). For academic criticism, see Julian Eule, Laying the Dormant Commerce Clause to Rest, 91 YALE L.J. 425, 427-28 (1982); Robert A. Sedler, The Negative Commerce Clause As a Restriction on State Regulation and Taxation: An Analysis in Terms of Constitutional Structure, 31 WAYNE L. REV. 885 (1985).

100. See CTS Corp., 481 U.S. at 95-96.

101. See Eule, supra note 99 , at 433 n. 40 .

102. See id. at 436.

103. One reason such a disparate burden might be present is that interstate entities might be subject to inconsistent regulations in different states, such as equipment rules for transportation that would cause added costs for interstate carriers as opposed to local ones. 
and proper disposal of other kinds of waste. Solid waste disposal is expensive in Oneida-Herkimer, but the Counties accept recyclables and many forms of hazardous waste for free, effectively encouraging their citizens to sort their own trash. Second, by requiring all waste to be deposited at Authority facilities, the Counties have markedly increased their ability to enforce recycling laws. If the haulers could take waste to any disposal site, achieving an equal level of enforcement would be much more costly, if not impossible. For these reasons, any arguable burden the ordinances impose on interstate commerce does not exceed their public benefits. $^{104}$

United Haulers is at least a signal that the majority of the Court is not engaged in a campaign to aggressively expand the dormant Commerce Clause, which is good news for state climate change regulators. United Haulers may also have some implications for climate regulations by upholding exclusive franchises to publicly owned utilities, which can then use their proprietary powers to purchase exclusively from low-carbon generators without fear of Commerce Clause challenges.

\section{B. State Climate Regulations and the Dormant Commerce Clause}

State climate change regulations may face dormant Commerce Clause claims as well. For example, efforts to reduce emissions by electrical generators may face claims that the regulations burden commerce, discriminate between instate and out-of-state firms, or are guilty of extraterritorial regulation. Assuming that states do not make the mistake of discriminating against out-of-state firms ${ }^{105}$ and that the proprietary exemption does not apply, their regulations will be reviewed under the balancing test. In applying the balancing test, one key factor is the strength of the state's regulatory interest.

States should find it easy to demonstrate the strength of their interest, given what we now know about climate change. One of the most predictable impacts is sea level rise, which will affect every coastal state. The Supreme Court has already found this harm to be serious enough and foreseeable enough to

104. United Haulers Ass'n v. Oneida-Herkimer Solid Waste Mgmt. Auth., $127 \mathrm{~S}$. Ct. 1786, 1798 (2007) (citation omitted).

105. As other commentators have explained in the context of California electricity regulation:

If California aims to stop leakage by treating electricity generated outside of California differently than electricity generated inside California, the state will almost certainly lose when facing a lawsuit based on dormant Commerce Clause grounds. This means that California should avoid making policy distinctions between in-state energy and out-of-state energy and create a process that is blind to the location of energy production. Similarly, if California attempts to stop leakage by attempting to regulate outside of California, the state will likely lose. This means that the incidence of regulation-the events upon which regulatory requirements are imposed-ought to be easily describable as occurring within California.

Chemerinsky et al., supra note 32 , at 10,658 . 
constitute a basis for standing by state governments. In Massachusetts v. EPA, the Court emphasized the existence of a semi-sovereign state interest in responding to climate change because of the threat posed to the state's citizens and even to its territory (as a result of sea level rise):

These rising seas have already begun to swallow Massachusetts' coastal land. Because the Commonwealth "owns a substantial portion of the state's coastal property," it has alleged a particularized injury in its capacity as a landowner. The severity of that injury will only increase over the course of the next century: If sea levels continue to rise as predicted, one Massachusetts official believes that a significant fraction of coastal property will be "either permanently lost through inundation or temporarily lost through periodic storm surge and flooding events." Remediation costs alone, petitioners allege, could run well into the hundreds of millions of dollars. $^{106}$

In addition, the IPCC has found it "very likely that hot extremes, heat waves, and heavy precipitation events will continue to become more frequent." 107 It also concurs that we are likely to see changes in tropical storms such as hurricanes: "[b]ased on a range of models, it is likely that future tropical cyclones (typhoons and hurricanes) will become more intense, with larger peak wind speeds and more heavy precipitation ...."108 These surely should be weighed as serious harms in the judicial scales.

One possible argument is that, although the states' interests are weighty, state legislation can only have a minimal effect in attaining those goals. This argument might be made against California's automobile standards for GHGs. This argument should fail. The Court rejected a similar argument in Massachusetts $v . E P A^{109}$ in considering whether a federal action was too minor to have any effect on climate change by itself:

Agencies, like legislatures, do not generally resolve massive problems in one fell regulatory swoop. They instead whittle away at them over time, refining their preferred approach as circumstances change and as they develop a more-nuanced understanding of how best to proceed. ${ }^{110}$

Similar reasoning suggests that state efforts to combat climate change should not be downgraded because they are only capable of making small steps toward curing what is, after all, a very large problem. Moreover, at least one circuit has recognized that an otherwise insignificant local effort can acquire significance because of its potential to inspire imitators. ${ }^{11}$ States, like federal agencies, should not be faulted for their inability to solve a large problem in one fell swoop.

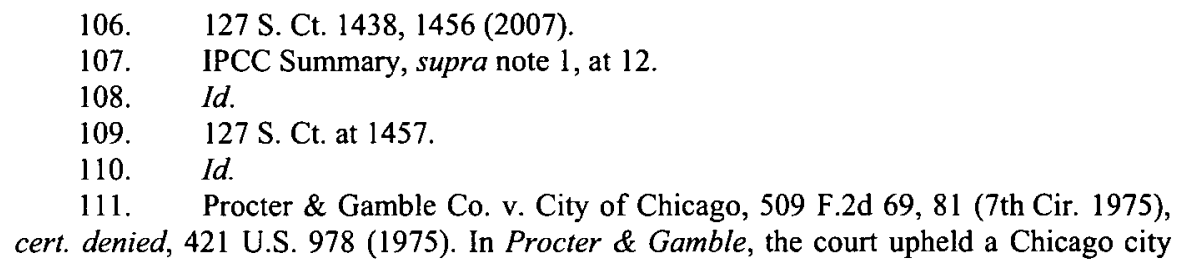

111. Procter \& Gamble Co. v. City of Chicago, 509 F.2d 69, 81 (7th Cir. 1975), cert. denied, 421 U.S. 978 (1975). In Procter \& Gamble, the court upheld a Chicago city 
Another aspect of dormant Commerce Clause doctrine may also pose obstacles to state regulation. The Supreme Court has sometimes spoken of a restriction on "extra-territorial" legislation under the dormant Commerce Clause. In Carbone, for example, the Court said that it would be illegitimate for a state to ban the export of waste for the purpose of protecting the environment outside of its borders. ${ }^{12}$ This suggests that states could only consider in-state harms from climate change in attempting to justify their regulations under Pike.

Just as extraterritorial benefits may not count, extraterritorial mandates may be forbidden by the Commerce Clause. In a case dealing with liquor pricing, the Court struck down a state law requiring liquor wholesalers to give "most favored nation" treatment to New York retailers, on the ground that this indirectly constrained what wholesalers could charge outside the state, thereby "projecting" its price regulation into other states. ${ }^{13}$ Such regulatory impacts on out-of-state commerce are apparently impermissible. The Court has not, however, done much to explain this rule or justify it. ${ }^{114}$ Apart from the Commerce Clause, restrictions on extraterritoriality are much more lenient and allow state regulation, except where the state has no meaningful connection with the regulated activity. ${ }^{115}$

The extraterritoriality problem is illustrated by the California PUC regulation discussed earlier. ${ }^{116}$ Recall that the regulation restricted long-term contracts by California utilities with suppliers, requiring that the suppliers meet greenhouse emissions requirements. Opponents argued that the PUC would be in effect regulating emissions by out-of-state generators. ${ }^{17}$ The PUC replied that the regulation did not have the effect of limiting contracts that out-of-state generators might make with non-California utilities, nor did the state directly regulate the

ordinance banning the sale of detergents containing phosphates. $I d$. at 72 . The Illinois River had nutrient concentrations well above the level where phosphates would be a limiting factor on algae, but the court viewed Chicago's ordinance as a first step toward limiting nutrients in that river. $I d$. at $80-81$. The court also found that the city had a "legitimate interest in banning phosphate detergents as an example for other communities presently releasing their sewage into Lake Michigan." Id. at 81 .

112. C \& A Carbone, Inc. v. Town of Clarkstown, 511 U.S. 383, 393 (1994).

113. Brown-Forman Distillers Corp. v. N.Y. State Liquor Auth., 476 U.S. 573, 585 (1986). The Court held a similar law applying to beer sales to be per se invalid because "the practical effect of the regulation is to control conduct beyond the boundaries of the State," preventing brewers from engaging in competitive pricing in a neighboring state based on prevailing market conditions. Healy v. Beer Inst., Inc., 491 U.S. 324, 336, 343 (1989) (citing Brown-Forman Distillers, 476 U.S. at 579).

114. For discussion of the extraterritoriality rule, see Daniel A. Farber, Stretching the Margins: The Geographic Nexus in Environmental Law, 48 STAN. L. REV. 1247, 1262 (1996).

115. See Allstate Ins. Co. v. Hague, 449 U.S. 302 (1981) (considering whether Minnesota's application of Minnesota state law in an insurance contract violated the Due Process Clause or the Full Faith and Credit Clause). At least this is true in civil cases, and the Court might well apply a similar analysis to criminal cases. See Richard H. Fallon, Jr., If Roe were Overruled: Abortion and the Constitution in a Post-Roe World, 51 ST. LOUIS U. L.J. 611, 626-32 (2007).

116. See supra text accompanying notes $40-48$.

117. PUC Order, supra note 41 , at 221. 
conduct of out-of-state firms, as opposed to regulating contracts with those firms. ${ }^{118}$

The problem is that the ban on extraterritoriality is logically incoherent. None of the cases in which the Court discussed this issue involved explicit regulation of out-of-state activities. Rather, they involved either regulations that strongly impacted competition in out-of-state markets or that were purportedly based in part on a desire to create out-of-state benefits. But the Court has not explained why these particular extraterritorial effects should be off-limits for states, nor how to distinguish them from similar but permissible interstate effects.

Another problem is that in a unified national market, any important state regulation is likely to have some spillover effects on other markets and possible benefits beyond the state lines. (Consider, for example, how Delaware's dominant role in corporate law affects the activities of corporations that do business around the world, many of which actually have no connection with Delaware except for their charters.) This will be especially true of a state with California's economic clout. Moreover, it seems artificial to consider the out-of-state harms of a regulation against the state law, but not to consider the out-of-state benefits in its favor. Congress would presumably consider the full range of costs and benefits in deciding whether to permit a state law, and there is no evident reason why courts should apply a different approach; in general, courts seem equally competent to assess local and interstate effects. ${ }^{119}$ Extraterritorial impacts are the justification for having a balancing test, rather than some unusual circumstance that warrants the creation of special rules. Rather than forming a per se rule, these effects on out-ofstate markets should be considered simply as part of the balancing test. Failing that, the extraterritoriality concept should be confined to the cases of direct interference with the regulatory authority of other states, lest it swallow up the balancing test.

In terms of climate legislation, extraterritoriality doctrines might block states from justifying their regulations in part on the basis of the benefits of climate

118. Id. The PUC relied on Gravquick A/S v. Trimble Navigation International, 323 F.3d 1219, 1224 (9th Cir. 2003) (upholding the application of a California statute to an international contract over a dormant Commerce Clause challenge, reasoning that the statute "does not directly regulate the actions of parties located in other states, it regulates contractual relationships in which at least one party is located in California.").

119. Certainly, in deciding whether regulatory benefits are sufficient to justify impinging on the national common market, the full range of benefits is relevant. Also, if we are concerned that state regulations might increase tensions between state governments, outof-state governments are likely to be mollified if the burdens of a regulation on their own citizens are outweighed by the benefits, though there might still be individual firms with an interest in litigating the question. (But perhaps not, if one state imposes the regulation, another experiences the burdens, and a third enjoys the benefits.) Perhaps one might argue that the role of courts is to uphold a national conception of citizenship; Congress does so simply because it represents the national citizenry but judges must prevent states from arrogating to themselves the balance of benefits and costs affecting those outside of their borders. Still, one might just as well argue that a state offends the concept of national citizenship if it fails to take due account of how its actions might benefit citizens of other states. 
mitigation to other states (or outside the United States). Moreover, regulations that impose sanctions on out-of-state actors or transactions, or that might be seen as doing so, may be vulnerable to challenge. Extraterritorial regulation seems discernible from interstate burdens only in terms of explicitness and directness. States should be careful that their regulations as a matter of form apply only to instate entities and transactions, and that impacts on out-of-state activities appear to be merely side-effects encountered in achieving legitimate local regulatory goals.

\section{PREemption}

The dormant Commerce Clause is an implicit constitutional limitation on state authority. It applies regardless of whether Congress has legislated in the same areas as the state (unless Congress authorizes the state regulation) or whether the President has taken a position on a subject. State authority is also subject to additional restrictions, however, when the federal government has acted.

Typically, these restrictions arise when Congress has enacted relevant legislation that in some way conflicts with state law. More rarely, a presidential or congressional action relating to foreign affairs may also preempt a state. Despite the purported attachment of some Justices to states' rights, the preemption doctrine has been alive and well, perhaps because the same Justices who believe in the inviolability of the states also believe in the inviolability of the market. ${ }^{120}$ In any event, when Congress passes climate change legislation, we can expect a spate of preemption claims. $^{121}$

\section{A. Statutory Preemption}

This section addresses the validity of state regulations in areas where Congress has acted, unlike the dormant Commerce Clause which operates regardless of federal legislation. ${ }^{122}$ It is clear, of course, that in cases of direct

120. As Richard Fallon puts it:

Whereas one might expect pro-federalism Justices to disfavor claims of federal preemption of state law, substantive conservatism may help to explain why the Court has so frequently upheld preemption claims in recent years. Because federal preemption eliminates state regulatory burdens, preemption rulings have a tendency-welcome to substantive conservatives- to minimize the regulatory requirements to which businesses are subject.

Fallon, supra note 81 , at 471 .

121. The situation prior to new federal legislation is primarily governed by the savings provision of the Clean Air Act, which allows states to impose regulatory standards beyond those of the federal government. If EPA adopts climate change regulations under the aegis of the Clean Air Act without the benefit of further legislation, any claim of preemption presumably would have to be based on a showing that the effect of state regulations was to dilute or impede the operation of the federal regulations. Conceivably, however, the federal government might argue that the savings clause applied only to state regulations of in-state pollution levels rather than regulations involving global pollutants such as carbon dioxide.

122. For general discussions of the preemption doctrine, see Caleb Nelson, Preemption, 86 VA. L. ReV. 225 (2000); Theodore W. Ruger, Preempting the People: The Judicial Role in Regulatory Concurrency and its Implications for Popular Lawmaking, 81 
conflict with federal law, the state statute must give way. ${ }^{123}$ Congress has the power to preempt state laws simply by enacting an express statutory provision to that effect. ${ }^{124}$ The presence of a contradiction between federal mandates and state law, however, is often less than obvious, leading some to question whether the Court has taken statutory preemption too far. ${ }^{125}$

A recent Supreme Court case illustrates the application of express preemption to environmental regulation. In the Engine Manufacturers case, ${ }^{126}$ the California air pollution agency with authority over the Los Angeles region had issued "Fleet Rules" that required certain operators of vehicle fleets, such as street sweepers and taxi companies, to purchase alternative fuel vehicles and low or zero emissions vehicles already approved for sale in California and commercially available. ${ }^{127}$ A provision of the Clean Air Act prohibits any state or political subdivision from adopting a "standard relating to the control of emissions from new motor vehicles or new motor vehicle engines." 128 As noted earlier, there is a special exception for certain California laws that did not apply in this case because the regulation was not statewide and there was no waiver application. In an opinion by Justice Scalia, the Court held that the Southern California rule was invalid on the basis of the plain statutory language: the rule related to emission characteristics of a vehicle or engine, which thus constituted a "standard"

ChI.-Kent L. REV. 1029 (2006); Paul S. Weiland, Federal and State Preemption of Environmental Law: A Critical Analysis, 24 HaRv. EnVTL. L. REV. 237 (2000).

123. The Supremacy Clause of the Constitution provides:

This Constitution, and the Laws of the United States which shall be made in Pursuance thereof; and all Treaties made, or which shall be made, under the Authority of the United States, shall be the supreme Law of the Land; and the Judges in every State shall be bound thereby, any Thing in the Constitution or Laws of any State to the Contrary notwithstanding.

U.S. CoNST. art. VI., $\S 1$, cl. 2. For a survey of recent cases in which state environmental regulation has been held preempted, see Robert L. Glicksman, From Cooperative to Inoperative Federalism: The Perverse Mutation of Environmental Law and Policy, 41 WAKE FOREST L. REV. 719, 787-91 (2006).

124. See Shaw v. Delta Air Lines, Inc., 463 U.S. 85, 95-96 (1983) (quoting Jones v. Rath Packing Co., 430 U.S. 519, 525 (1977)). A recent example is Riegel v. Medtronic, Inc., 128 S. Ct. 999, 1006-11 (2008) (holding that state tort law regarding defective medical devices was preempted by federal regulatory statute). Administrative agencies may also have this power where authorized by Congress. See Hillsborough County v. Automated Med. Labs., Inc., 471 U.S. 707, 713 (1985). Similarly, if Congress determines that state regulation should not be preempted by a federal statute, Congress may expressly say so in a "savings clause" in the statute. See 33 U.S.C. $\$ 1365$ (2006).

125. Preemption doctrine has not received nearly the attention it should, particularly from advocates of federalism. See Emest A. Young, The Rehnquist Court's Two Federalisms, 83 TEX. L. REV. 1, 130-34 (2004) ("The first priority of federalism doctrine ought to be limiting the preemptive impact of federal law on state regulation.").

126. Engine Mfrs. Ass'n v. S. Coast Air Quality Mgmt. Dist., 541 U.S. 246 (2004).

127. Id. at $248-49$.

128. Id. at 252 (quoting 42 U.S.C. $\S 7543($ a) (2000)). 
preempted by the federal statute. ${ }^{129}$ The Court was unmoved by the fact that mobile source emissions were the leading contributor to toxic and conventional air pollution in the region. Similar preemption issues may be raised by state laws addressing emission of GHGs by vehicles. ${ }^{130}$

The absence of express preemption may not be enough to save a state law. The Supreme Court has set forth various factors for courts to consider in preemption cases where the statute does not directly address preemption. ${ }^{131}$ First, the federal regulatory scheme may be so pervasive and detailed as to suggest that Congress left no room for the state to supplement it. The statute enacted by Congress may involve a field in which the federal interest is so dominant that enforcement of state laws is precluded. Other aspects of the regulatory scheme imposed by Congress may also support the inference that Congress has completely foreclosed state legislation in a particular area. This is often called "field" preemption. $^{132}$ Even where Congress has not completely foreclosed state regulation, a state statute is void to the extent that it actually conflicts with a valid federal statute. Such a conflict can be found where compliance with both the federal and state regulations is impossible, or more often, where the state law interferes with the accomplishment of the full objectives of Congress. ${ }^{133}$

These factors are obviously vague and difficult to apply. The Supreme Court has done little to create a more rigorous framework for analysis. Indeed, even when a statute contains an express preemption or savings clause, ${ }^{134}$ application of the statutory language may involve difficult problems of interpretation. Therefore, the only way to achieve some degree of understanding of the field is to examine particular cases in order to see what situations have been deemed appropriate for application of the preemption doctrine.

Every preemption case is unique. Apart from some vague and usually unhelpful maxims, little can be said about this area of law that is of much help in deciding individual cases. Indeed, critics contend that, "[n]otwithstanding its repeated claims to the contrary, the Supreme Court's numerous preemption cases

129. Id. at 258 .

130. See, e.g., Carlson, supra note 50, at 290-92 (2003).

131. When the statute addresses the subject, the issue is one of express preemption. For a skeptical view of such statutory provisions, see Kirsten H. Engel, Harnessing the Benefits of Dynamic Federalism in Environmental Law, 56 EMORY L.J. 159, 184 (2006) (stating that preemption can be considered "an unpleasant by-product of interest group law making."). Note that Congress can also enact savings clauses which allow state regulation that would otherwise be preempted.

132. This form of preemption is discussed in Rice v. Santa Fe Elevator Corp., 331 U.S. 218,230 (1947).

133. One example is McDermott v. Wisconsin, 228 U.S. 115 (1913), where following federal labeling rules would have resulted in food being mislabeled under state law. Id. at $125-26$.

134. The operation of savings clauses is discussed in Robert L. Fischman \& Angela M. King, Savings Clauses and Trends in Natural Resources Federalism, 32 WM. \& MARY ENVTL. L. \& POL'Y REV. 129 (2007). The authors conclude that the "abstract and broad language of savings clauses ... allow courts as well as agencies to see in them a mirror of their own conceptions of cooperative federalism." Id. at 161 . 
follow no predictable jurisprudential or analytical pattern." 135 The question before the Court in each case is whether Congress, in passing a particular statute, would have been willing to allow the state to impose certain kinds of regulations in the same area. This is essentially an issue of statutory construction. It can only be resolved by close attention to the language of the federal statute, to its legislative history, to its purposes, and to the content and effect of the state law in question. Thus, the best advice for lawyers in analyzing preemption problems is to probe the legislative materials and the extent to which the state statute would have a practical effect on the implementation of the federal statute. The results of such inquiries, however, are not necessarily clear.

Perhaps in response to the difficulty of applying the standard preemption tests, the Supreme Court has enunciated a presumption against preemption. For example, in a decision dealing with state tort remedies against cigarette companies, the Court said that it "'start[s] with the assumption that the historic police powers of the States [are] not to be superseded by ... Federal Act unless that [is] the clear and manifest purpose of Congress." 136 It is not clear, however, how significant this presumption is in practice. The Court often finds that state laws are preempted by federal statutes even where reasonable minds (sometimes including four Justices) might disagree with that conclusion. ${ }^{137}$ States will undoubtedly rely on this generalized presumption in their defense of climate change regulation, but how much actual ground they will gain is unclear.

Another wrinkle regarding federal preemption is provided by decisions of federal administrative agencies to preempt state law. The Court has given weight to such regulations. ${ }^{138}$ Whether strong deference to agency views on preemption is appropriate remains controversial. ${ }^{139}$ Depending on whether the EPA is supportive of state regulation, its views on preemption issues may either assist states or create an additional obstacle to state climate regulation.

135. Viet D. Dinh, Reassessing the Law of Preemption, 88 GEO. L.J. 2085, 2085 (2000).

136. Cipollone v. Liggett Group, Inc., 505 U.S. 504, 516 (1992) (quoting Rice v. Santa Fe Elevator Corp., 331 U.S. 218, 230 (1947)).

137. See Calvin Massey, "Joltin' Joe has Left and Gone Away": The Vanishing Presumption Against Preemption, 66 ALB. L. REV. 759 passim (2003).

138. See Geier v. Am. Honda Motor Co., 529 U.S. 861, 874 (2000) (holding action against car company for improper design of airbag preempted in part on the potential interference of such a tort action with the DOT's decision to phase in new airbag requirements); Medtronic, Inc. v. Lohr, 518 U.S. 470, 496 (1996) (suggesting that agency views on preemption are entitled to consideration by the courts and preempting state law). In other settings, the Court has upheld state regulations that should arguably have been preempted See, e.g., Silkwood v. Kerr-McGee, 464 U.S. 238 (1984) (declining to preempt state tort law that allowed award of punitive damages against utility, even if utility complied with all federal safety regulations).

139. For arguments against such deference, see Nina A. Mendelson, Chevron and Preemption, 102 MICH. L. REV. 737 (2004) and David C. Vladeck, Preemption and Regulatory Failure, 33 PEPP. L. REV. 95 (2005). See also Catherine M. Sharkey, Preemption by Preamble: Federal Agencies and the Federalization of Tort Law, 56 DEPAUL L. REV. 227 (2007). 
As Congress becomes more involved with the issue, climate change is bound to present cases in which there is no clear basis for resolving the preemption issue and results are therefore likely to be unpredictable. Part III(B) will examine how to resolve these issues, with particular attention to the possible preemptive effect of a federal cap-and-trade scheme. First, we need to consider another type of preemption.

\section{B. Foreign Affairs Preemption}

Apart from ordinary statutory preemption, state laws may also be subject to challenge because they trammel on federal prerogatives over foreign affairs. Unfortunately, constitutional doctrine seems to be in flux on this issue. ${ }^{140}$ Climate change is obviously a global problem that will ultimately require concerted international action, but this does not necessarily mean that it is part of that realm of "foreign affairs" reserved to the federal government. The caselaw, alas, is maddeningly underdeveloped.

The Supreme Court recently issued two opinions dealing with implied restrictions on state regulatory authority affecting foreign affairs. ${ }^{141}$ The first case was Crosby v. National Foreign Trade Council. ${ }^{142}$ In 1996, the Commonwealth of Massachusetts passed a law that prohibited state or local governments from doing business with companies that were themselves doing business with Burma. ${ }^{143}$ The Court held that the state law was preempted by federal legislation imposing sanctions on Burma. ${ }^{144}$ Congress had enacted initial sanctions but gave the President the power to end the sanctions if he certified that Burma had made progress on human rights; he also had the power to re-impose sanctions in case of

140. For discussions of the evolving doctrine, see Chemerinsky et al., supra note 32, at 10,659-64 (reviewing the doctrine's development and application to state climate change legislation); Jack Goldsmith, Statutory Foreign Affairs Preemption, 2000 SUP. CT. REV. 175, 177 (2001) ("[Courts] should eschew independent judicial foreign policy analysis, and preempt state law only on the basis of policy choices traceable to the political branches in enacted law."); Judith Resnick, Foreign as Domestic Affairs: Rethinking Horizontal Federalism and Foreign Affairs Preemption in Light of Translocal Internationalism, 57 EMORY L.J. 31 (2007).

141. Two earlier decisions are also worth noting. In Toll v. Moreno, 458 U.S. 1, 17 (1982), the Court struck down a state law that imposed higher college tuition on certain aliens (those with special visas for individuals affiliated with certain international organizations and their families). The Court noted the "preeminent role of the Federal Government with respect to the regulation of aliens within our borders." Id. at 10. The Court held that states may not impose additional burdens on any category of legal aliens without Congressional approval. Id. at 12-13. In Banco Nacional de Cuba v. Sabbatino, 376 U.S. 398, 424-25 (1964), the Court held that states have no power to determine the validity of the acts of foreign nations in contravention to the federal act of state doctrine. "[W]e are constrained to make it clear," the Court said, "that an issue concerned with a basic choice regarding the competence and function of the Judiciary and the National Executive in ordering our relationships with other members of the international community must be treated exclusively as an aspect of federal law." Id.

142. 530 U.S. $363(2000)$.

143. Id. at $366-67$.

144. Id. at 388 . 
back-sliding and to suspend sanctions in the interest of national security. ${ }^{145}$ The Court found it implausible that Congress would have given such broad authority to the President while allowing states to undermine the effect of his decisions. ${ }^{146}$ Also, the state sanctions went further than the federal sanctions. ${ }^{147}$ Hence, the Court concluded that the state law interfered with the President's statutory discretion to control economic sanctions against Burma. ${ }^{148}$

Moreover, the Court also held that the state law conflicted with the congressional directive for the President to help develop a multinational Burma strategy. ${ }^{149}$ In effect, the state law would have undermined the President's ability to engage in effective diplomacy. ${ }^{150}$ Indeed, the state law had already resulted in World Trade Organization complaints against the United States, causing conflict rather than promoting international cooperation in dealing with Burma. ${ }^{151}$ As the Court said, the state law "compromise[s] the very capacity of the President to speak for the Nation with one voice in dealing with other governments."

Crosby seems a very cautious ruling. The Court eschewed the possibility of a broader holding that would address foreign affairs preemption even when the federal government has taken no action. Instead, it essentially found a conflict with congressional legislation, venturing little beyond the ordinary parameters of statutory preemption. ${ }^{153}$

The Court's more recent ruling in American Insurance Ass'n $v$. Garamendi, ${ }^{154}$ is potentially more sweeping but also more difficult to interpret. The State of California had passed legislation dealing with World War II-era insurance policies held by European Jews, many of which were either confiscated by the Nazis or dishonored by insurers who denied the existence of the policy or claimed that it had lapsed from unpaid premiums. ${ }^{155}$ Ultimately, the Allied governments mandated restitution to Nazi victims by the West German government. ${ }^{156}$ Unfortunately, although a large number of claims were paid, many others were not, and large-scale litigation resulted after German reunification. ${ }^{157}$ The U.S. government entered into negotiations to try to resolve the dispute, resulting in an agreement about insurance compensation. ${ }^{158}$ Under the agreement, the German government agreed to establish a foundation with ten billion deutschmarks of funding to compensate the victims of insurance company recalcitrance, while the U.S. government pledged to try to get U.S. state and local

$\begin{array}{ll}145 . & I d . \text { at } 369-70 . \\ 146 . & I d . \text { at } 376 . \\ 147 . & I d . \\ 148 . & I d . \text { at } 377 . \\ 149 . & I d . \text { at } 380-81 . \\ 150 . & I d . \text { at } 381 . \\ 151 . & I d . \text { at } 383 . \\ 152 . & I d . \text { at } 381 . \\ 153 . & \text { See } \text { id. } \text { at } 380-81 . \\ 154 . & 539 \mathrm{U} . \mathrm{S} .396(2003) . \\ 155 . & I d . \text { at } 401-02 . \\ 156 . & I d . \text { at } 403 . \\ 157 . & I d . \text { at } 403-04 . \\ 158 . & I d . \text { at } 405-06 .\end{array}$


governments (and courts) to respect the agreement as a complete settlement. ${ }^{159}$ The agreement did not purport to invalidate state laws, and clearly did not invalidate those laws in and of itself..$^{160}$ In the meantime, California passed a law requiring any insurer doing business in the state to disclose information about all policies sold in Europe between 1920 and $1945 .{ }^{161}$ California officials were unmoved by a protest from the federal government that the statute would possibly derail its agreement with Germany. ${ }^{162}$

The Court divided 5-4. ${ }^{163}$ Interestingly, the line-up did not correspond to the usual liberal-conservative split on the Court. The majority included a conservative (Chief Justice Rehnquist) and four of the Court's centrist Justices (Souter, O'Connor, Kennedy, and Breyer), while the dissent contained liberals (Ginsburg and Stevens) as well as the Court's most conservative members (Scalia and Thomas). ${ }^{164}$

The majority found the California law invalid as an interference with presidential foreign policy. ${ }^{165}$ According to the majority, the consistent presidential policy had been to encourage voluntary settlement funds in preference to litigation or coercive sanctions. ${ }^{166}$ California sought to place more pressure on foreign companies than the president had been willing to exert. ${ }^{167}$ This clear conflict between express foreign policy and state law was itself a sufficient basis for preemption. ${ }^{168}$ As the Court said, California used "an iron fist where the President has consistently chosen kid gloves." 169 The majority found the preemption issue particularly clear, given the weakness of the state's interest in terms of traditional state legislative activities. ${ }^{170}$

Justice Ginsburg's dissent made several cogent points. First, the state law only mandated information disclosure rather than coercing payment of claims. ${ }^{171}$ Second, the President had not entered into any formal executive agreement purporting to settle the claims of American Holocaust survivors or their descendants against foreign insurance companies. ${ }^{172}$ Such an agreement would clearly have had preemptive effect, while the actual agreement was far more limited. Third, Justice Ginsburg said upholding the state law "would not compromise the President's ability to speak with one voice for the Nation"; "[t]o the contrary," by declining to do so, "we would reserve foreign affairs preemption

$\begin{array}{ll}\text { 159. } & I d . \\ 160 . & \text { See id. at } 406 . \\ 161 . & I d . \text { at } 408-10 . \\ 162 . & I d . \text { at } 411-12 . \\ 163 . & I d . \text { at } 400 . \\ 164 . & I d . \\ 165 . & I d . \text { at } 427 . \\ 166 . & \text { See } \text { id. at } 420,426-27 . \\ 167 . & \text { See } \text { id. at } 426 . \\ 168 . & I d . \text { at } 427 . \\ 169 . & I d . \text { at } 427 . \\ 170 . & I d . \text { at } 420-21 . \\ 171 . & I d . \text { at } 435 . \\ 172 . & I d . \text { at } 440-41 .\end{array}$


for circumstances where the President, acting under statutory or constitutional authority, has spoken clearly to the issue at hand."173

Garamendi, if read broadly, would arguably preempt virtually any state regulation dealing with a matter that was also the subject of foreign negotiations. This might include many issues of great importance to states. Modern foreign affairs covers a gamut of issues from women's rights to endangered species to criminal justice, and it would be extraordinary if the states were preempted from all of these areas merely because of their potential entanglement with foreign affairs-for example, the possibility that the President might someday wish to negotiate about an issue and would find a lack of existing domestic regulation useful as a bargaining chip. It would also be extraordinary if any presidential action, however slight, or any announced reluctance to act, was enough to oust the states from otherwise valid regulations. Thus, it would be wrong to read Garamendi for all it is worth.

A narrower reading is readily available. A key aspect of the case was that California was using a very small local interest in protecting a small number of its residents to force foreign entities to take actions regarding events outside its borders (concerning the issuance or failure to pay on foreign insurance policies), and both the events and California's policy overwhelmingly affected non-U.S. interests. ${ }^{174}$ Moreover, the issue was one that arose only because of the past acts of a foreign sovereign (Germany). ${ }^{175}$ Thus, the international aspect of the issue completely dwarfed any state dimension. In the arena of climate change, as Massachusetts v. EPA makes clear, the state's interest is much stronger, and furthermore, the regulations are directed at modifying future conduct that takes place entirely within the state. ${ }^{176}$ Finally, as the Court in Massachusetts v. EPA also observed, there is as of yet no clearly articulated presidential policy that would preclude domestic regulation. ${ }^{177}$

A related restriction on state authority is the Compact Clause, which provides that "No State shall, without the Consent of Congress ... enter into any Agreement or Compact with another State, or with a foreign Power . .." ${ }^{178}$ As applied to interstate agreements, the Supreme Court has not construed this provision to ban all agreements between states, but only those that are "directed to the formation of any combination tending to the increase of political power in the states, which may encroach upon or interfere with the just supremacy of the United States." 179 On this basis, the Court upheld the formation of a multi-state tax commission formed to develop tax policy for individual states, when that policy would be adopted separately by each state. ${ }^{180}$ The commission had the power to conduct audits using subpoenas in any of the member states' courts, including

174. See id. at $408-09$.

175. See id. at 401-03.

176. 127 S. Ct. 1438,1455 (2007).

177. See id. at 1463.

178. U.S. ConST. art. I, $\S 10, \mathrm{cl} .3$.

179. Virginia v. Tennessee, 148 U.S. 503, 519 (1893).

180. U.S. Steel Corp. v. Multistate Tax Comm'n, 434 U.S. 452, 479 (1978). 
audits of multinational corporations. Similarly, the Court upheld a multi-state agreement on regional banking which contained reciprocity provisions but did not prohibit withdrawal from the regional requirements. ${ }^{181}$

Thus, although the states may be limited in their ability to form multistate regulatory authorities without congressional approval, policy coordination between states does not seem to pose the same kind of challenge to national authority. Thus, if a number of states coordinate on the adoption of similar climate change regulations and allow trading between their emission sources, the Compact Clause should not be implicated, provided that regulatory authority and enforcement powers continue to be held by the states themselves rather than by some interstate agency. For this reason, the RGGI trading system between the Northeast states does not appear to pose a problem under the Compact Clause.

In terms of agreements between the states and foreign governments, the application of the Compact Clause seems murky. Another provision of the Constitution prohibits "treaties" between states and foreign powers, with no provision for congressional waiver of the prohibition. Thus, there are four categories of international cooperation:

(1) informal undertakings that do not rise to the level of explicit intergovernmental obligations;

(2) explicit arrangements that are not sufficiently sweeping to constitute "compacts";

(3) "compacts" that are invalid unless approved by Congress; and

(4) "treaties" that are invalid even with congressional approval.

The cases discussed immediately above, dealing with agreements between states, are instructive regarding the distinctions between categories one, two, and three. Thus, the category of agreements that can be subject to unilateral executive agreement may provide guidance about the category that can be subject to state agreement (at least with the consent of Congress). Indeed, because the text is identical, the precedents dealing with interstate agreements are arguably transferable to determining the validity of state-foreign agreements. On the other hand, such agreements implicate somewhat different foreign affairs interests, and there may be an argument for modifying the test even though doing so would be quite awkward, textually. It would require saying that the terms agreement and compact mean different things within the same clause, "any Agreement or Compact with another State, or with a foreign Power."

As to the fourth category, we might by analogy consider that "treaties" must be ratified by the U.S. Senate while executive agreements are not subject to ratification. Surely, states may not enter into agreements pertaining to war and peace, and it seems plausible to assume they probably cannot enter into agreements with governments that are not recognized by the United States, because entering into discussions with those governments might be considered to infringe on the President's exclusive power to "receive ambassadors" under Article II.

181. Northeast Bancorp, Inc. v. Bd. of Governors, 472 U.S. 159, 175-76 (1985). 
The Compact Clause's coverage of agreements with foreign powers sheds light on foreign affairs preemption. It is legitimate for states to negotiate with foreign powers to create such compacts; the Clause does not require prior consent from Congress. Moreover, at least in theory, a state could enter into a compact even over the express objections of the President, if Congress was to give its consent and then override a presidential veto. Thus, whatever preemptive power may be held by the President seems narrower than Congress's power of preemption. This observation may have some general implications for foreign affairs preemption since it indicates that the President's authority over foreign relations is less than plenary.

It is not clear how seriously we should take foreign affairs preemption in the arena of climate change. Due to the lack of federal activity to date, there is little possibility of a direct conflict with any executive or congressional action; and since the president has not yet pursued binding international climate change obligations, there is no interference with negotiations. ${ }^{182}$ To the extent that any international understanding has been made by states, it does not seem to involve any direct exercise of governmental power by a joint entity or any binding obligation on the state to enact legislation. Without at least a presidential assertion that state climate regulations are interfering with an existing international agreement or with on-going international negotiations, there seems little basis for finding foreign affairs preemption. Ironically, replacement of President Bush with a chief executive who is more active in international climate negotiations would increase the threat that state climate regulations would be preempted, unless the president made it clear that they were consistent with his efforts. In the meantime, however, the key cases dealing with foreign affairs preemption seem distinguishable.

Moreover, the Supreme Court's only ruling on climate change to date, Massachusetts $v$. EPA, ${ }^{183}$ contains some signals that might undermine a preemption claim. First, Garamendi includes the strength of the state's regulatory interest as a factor in assessing foreign affairs preemption. ${ }^{184}$ As we have seen, Massachusetts $v$. EPA speaks strongly to the legitimacy and strength of the states' interests in addressing climate change. ${ }^{185}$ This assessment of the seriousness of a state's interest should weigh in its favor in considering foreign affairs preemption.

Second, although not directly addressing foreign affairs preemption, the Court made it clear that foreign affairs consideration could not override the otherwise plain language of federal pollution legislation. Responding to the government's claim that regulating carbon dioxide emissions under existing federal law might "impair the President's ability to negotiate with 'key developing nations' to reduce emissions," "186 the Court in Massachusetts v. EPA said:

182. See Note, Foreign Affairs Preemption and State Regulation of Greenhouse Gas Emissions, 119 HARV. L. REV. 1877, 1881-88 (2006).

183. 127 S. Ct. $1438(2007)$.

184. 539 U.S. $396,420-21$ (2003).

185. See $127 \mathrm{~S}$. Ct. at 1455.

186. Id. at 1463 . 
Although we have neither the expertise nor the authority to evaluate these policy judgments, it is evident they have nothing to do with whether greenhouse gas emissions contribute to climate change. Still less do they amount to a reasoned justification for declining to form a scientific judgment. In particular, while the President has broad authority in foreign affairs, that authority does not extend to the refusal to execute domestic laws. In the Global Climate Protection Act of 1987, Congress authorized the State Department - not EPA- to formulate United States foreign policy with reference to environmental matters relating to climate. See $\S 1103(\mathrm{c}), 101$ Stat. 1409. EPA has made no showing that it issued the ruling in question here after consultation with the State Department. Congress did direct EPA to consult with other agencies in the formulation of its policies and rules, but the State Department is absent from that list. $\S 1103(\mathrm{~b}){ }^{187}$

In terms of its bearing on preemption of state law, this language has limited force, since that issue was not before the Court. Nevertheless, the Court seemed skeptical of claims that domestic climate change actions should be invalidated because of interference with presidential foreign policy efforts. Assuming that changes in the make-up of the Court do not lead to a retreat from Massachusetts v. EPA, the implication seems to be favorable for state legislation on the subject-though the sparse Supreme Court caselaw on foreign affairs preemption and its somewhat Delphic pronouncements definitely leave uncertainty about the ultimate outcome. ${ }^{188}$ As noted earlier, the initial decisions in the litigation over California's proposed GHG limitations for vehicles rejected claims of foreign affairs preemption. ${ }^{189}$ For now, at least, foreign affairs preemption does not seem to be among the most serious threats to the validity of state climate regulation.

\section{The Future of Climate Change Federalism}

Federal action on climate change seems increasingly likely in light of current political developments. Federal legislation will potentially raise two federalism issues. First, does Congress have the power to legislate over all aspects of the problem? Issues of federal power regarding climate change were not

187. Id.

188. Some of the uncertainties about foreign affairs preemption are described in Chang:

The current state of the foreign affairs preemption doctrine and its future direction are unclear. Whether there is even any real doctrine of dormant foreign relations preemption, or when it applies; whether the dormant foreign Commerce Clause has broader preemptive effect than the dormant Commerce Clause . . . are just a few of the many unanswered questions that plague the jurisprudence.

Chang, supra note 34 , at 10,784. For an argument for giving Garamendi a narrow reading, see Kimberly Breedon, Garamendi's Unspoken Assumptions: Assessing Executive Foreign Affairs Preemption Challenges to State Regulation of Greenhouse Gases, [2007] 37 Envtl. L. Rep. (Envtl. Law Inst.) 10,897.

189. See supra text accompanying notes $58-67$. 
discussed earlier in this Article because they have not yet arisen, but sooner or later, they will arise if Congress becomes serious about addressing the full spectrum of climate issues. Second, once Congress has acted, what remaining role may the states play? This is partly a matter of preemption (statutory and otherwise) and partly involves the dormant Commerce Clause.

\section{A. Federal Power and Climate Change Regulation}

Between 1940 and 1990, the commerce power seemed effectively unlimited. Cases such as Hodel $v$. Indiana ${ }^{190}$ gave such a high degree of deference to Congress that almost any imaginable statute seemed likely to be upheld. ${ }^{191}$ For this reason, the Court's decision in United States v. Lopez ${ }^{192}$ surprised many observers. A majority of the Court in Lopez departed from almost sixty years of past practice by ruling that Congress had exceeded its powers under the Commerce Clause in a regulation of private activity. ${ }^{193}$ Specifically, the Court struck down a federal statute prohibiting the possession of firearms in the vicinity of schools. ${ }^{194}$

Chief Justice Rehnquist's opinion for the five-Justice majority in Lopez attempted to erect a limit on the commerce power, without overruling any cases or imperiling any well-entrenched federal programs. The opinion begins by invoking the original understanding that federal powers are "few and defined," while state powers are "numerous and indefinite." 195 Rehnquist emphasized that the original function of this division of powers was to assist in preserving liberty. ${ }^{196}$ Admittedly, he added, the scope of federal power had greatly increased in the postNew Deal era, partly because of "great changes" in the economy and partly because of a desire to eliminate what were considered "artificial" restraints on federal power. ${ }^{197}$ Having analyzed the post-New Deal caselaw, however, Rehnquist concluded that the school gun law did not fall squarely within the previously recognized scope of congressional power, and he declined to expand that scope further ${ }^{198}$ In reaching this conclusion, he noted that the statute related to education, traditionally a core area of state concern; that Congress had made no findings at the time about the effect of the prohibited activity on interstate commerce; and that the statute required no proof of any nexus between the defendant's activity and interstate commerce. ${ }^{199}$

190. 452 U.S. 314 (1981).

191. Id. at 322-27 (applying the rational basis test and concluding that the effect of strip mining on agriculture was large enough to justify congressional regulation under the Commerce Clause, even though mining affected only $0.006 \%$ of the total prime farmland acreage).

192. 514 U.S. 549 (1995).

193. Id. at $567-68$.

194. Id. at 551-52.

195. Id. at 552 (quoting THE FEDERALIST No. 45, at 292-93 (James Madison) (Clinton Rossiter ed., 1961).

196. Id. (citing Gregory v. Ashcroft, 501 U.S. 452, 458 (1991)).

197. Id. at 556.

198. Id. at 567-68.

199. Id. at $561-65$. 
The Supreme Court has yet to declare any federal environmental regulation of private entities to be outside the scope of Congress's commerce power. Nevertheless, the Court used Lopez as a justification to read the Clean Water Act narrowly in Solid Waste Agency of Northern Cook County v. U.S. Army Corps of Engineers (SWANCC). ${ }^{200}$ The question before the Court was whether SWANCC needed a federal permit before filling an abandoned gravel pit that had turned into a pond. ${ }^{201}$ Under the statute, federal jurisdiction covers "navigable waters," further defined as the "waters of the United States."202 The government asserted jurisdiction over the gravel pit under the Army Corps" "migratory bird" regulation, which claims jurisdiction over intrastate waters that can be used by migratory birds. ${ }^{203}$ The Supreme Court held that the regulation went beyond the Corps' statutory authority. ${ }^{204}$ The Court expressed considerable doubt about whether the Commerce Clause would support the migratory bird rule, and construed the statute to avoid this constitutional doubt. ${ }^{205}$ Finding "nothing approaching a clear statement from Congress," the Court rejected what it viewed as a "significant impingement of the States' traditional and primary power over land and water use." ${ }^{, 206} \mathrm{~A}$ more recent case ${ }^{207}$ attempts (not very successfully) to provide guidelines regarding which wetlands fall within the federal government's statutory authority but notably fails to explore potential constitutional concerns. ${ }^{208}$ $S W A N C C$ is disturbing because the Court's failure to recognize the protection of migratory birds is beyond the competence of any single state, and instead involves a collective action problem justifying federal intervention. Perhaps the Court considered this goal too remote from the general purpose of the Clean Water Act to be relevant. Or more disturbingly, perhaps the Court considered the functional needs of the governance system to be irrelevant to interpreting the statute or the Constitution.

The scope of Lopez remains unclear. In Gonzales v. Raich, ${ }^{209}$ the Court placed an important limitation on Lopez by reaffirming that Congress can regulate purely local activities if they are part of a class of activities that have a substantial cumulative effect on interstate commerce, where excluding the local activities

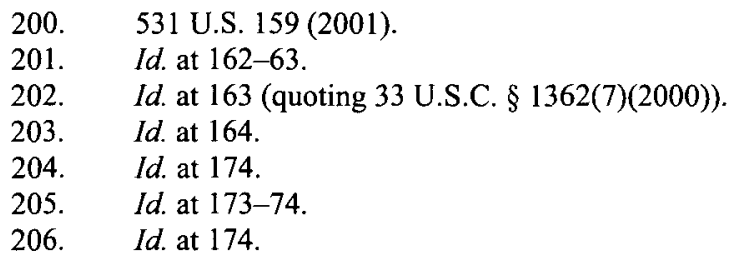

207. Rapanos v. United States, 547 U.S. 715 (2006). For an analysis of the contesting worldviews behind the various opinions in the case, see Jonathan Z. Cannon, Words and Worlds: The Supreme Court in Rapanos and Carabell, 25 VA. ENVTL. L.J. 277 (2007).

208. For attempts to sort out the mess, see Bradford C. Mank, Implementing Rapanos-Will Justice Kennedy's Significant Nexus Test Provide a Workable Standard for Lower Courts, Regulators, and Developers?, 40 IND. L. REV. 291 (2007); Jon A. Mueller, Adjacent Wetlands: Is Your Nexus Significant? Rapanos v. United States, 38 Env't. Rep. (BNA) 585 (Mar. 9, 2007). A recent illustrative case is Friends of Pinto Creek v. EPA, 504 F.3d 1007 (9th Cir. 2007).

209. 545 U.S. 1 (2005) 
from regulation might undermine the regulation of the interstate market. Justice Scalia emphasized in a concurring opinion that the regulation in Lopez had not been part of a larger regulation of economic activity. ${ }^{210}$ Thus, there seems to be a solid majority for allowing regulation even of purely "local" activities as an ancillary part of comprehensive federal regulation.

Climate change provides a powerful example of the folly of drawing artificial distinctions between the local and the interstate, or between economic and non economic activities, when Congress addresses complex systemic issues. All carbon dioxide sources and sinks are relevant to addressing climate change, making distinctions between types of sources irrelevant in terms of policy.

Artificial restrictions on jurisdiction make particularly little sense in terms of establishing a cap-and-trade scheme. For example, suppose that as part of the federal response to $S W A N C C$, the government was to allow banking of isolated wetlands (over which it does not have jurisdiction) to be used for mitigation by developers of other wetlands over which it does have jurisdiction. ${ }^{211}$ Such use of isolated wetlands for mitigation would not exceed the commerce power, because only non-isolated wetlands, over which the government does have jurisdiction, are actually regulated. That the owners of such covered wetlands choose to meet their mitigation obligations through restoration or preservation of isolated wetlands is not the government's regulatory mandate.

Similarly, cap-and-trade schemes could allow the federal government to reach what might otherwise be highly localized activities, arguably outside its authority under Lopez. For instance, firms might enter into agreements with cities to ban the use of wood fireplaces in homes, as a way to offset the firms' carbon emissions. In return for receiving valuable funding from the firms or attracting new business, the city would pass a regulation that might not otherwise have sufficient political support. The federal government could not pass such a regulation, and probably could not pass a law solely for the purpose of regulating wood fireplaces. Nevertheless, it can attain the same result through the incentives created by a broader trading system. This is an illustration of the Raich phenomenon - what could not be regulated in isolation may very well fall within the valid sweep of a systematic federal regulatory scheme.

Arguably, once a banking system is established, the banking system itself becomes a form of interstate commerce, justifying federal regulation because the isolated wetlands are now directly involved in interstate transactions. This may seem like a form of boot-strapping, but in theory the federal government's power over commerce should not depend on whether the market in question is "natural" or created by government intervention. For example, the market in federal bonds is surely a form of interstate commerce subject to federal regulation. No doubt that the Court would be quite skeptical if it appeared that a trading system was established or intrastate actors included within the market solely to establish a

210. Id. at 36 (Scalia, J., concurring). For discussion of the environmental implications of Raich, see Bradford C. Mank, After Gonzales v. Raich: Is the Endangered Species Act Constitutional Under the Commerce Clause?, 78 U. CoLO. L. REV. 375 (2007).

211. One difficult problem in designing such a system is to prevent the award of credits for lands that would not have been developed in any event. 
foothold for the commerce power. But the Court might be more sympathetic if the federal market merely subsumed preexisting state markets or if the inclusion of the intrastate sources took place as the result of private initiatives.

Thus, a carbon trading system might well provide for a wide variety of offsets, some of which might not be within direct congressional regulatory authority. Such offsets could include regulatory actions by state and local governments (which Congress could not mandate under the so-called "anticommandeering" doctrine). Offsets might also include noncommercial activities (enforceable agreements by groups of individuals to cease using wood fires in the home, plant trees, or modify their automobile usage). Some of these efforts to influence individual behavior may not be successful or may not be sufficiently easy to monitor, but they should not be ruled out in principle. Once they become part of the offset system, however, these activities cannot plausibly be described as beyond the domain of the federal government. ${ }^{212}$ If the federal government can make these activities part of the "currency" used in mitigation, it should be able to take steps to control that currency and maintain its integrity.

It would be especially ironic to decide that some aspects of the climate change problem were outside of federal jurisdiction. Part I discussed the slew of attacks on state regulations for invading what challengers consider to be a matter of exclusively national policy. In this setting, it would be peculiar to then decide that aspects of climate change were so intrinsically local that federal action was barred. ${ }^{213}$ Whatever we might say about climate change, it is assuredly not a purely local problem.

Traditionally, state and local governments have been the major regulators of land use and urban development. Responding to climate change may result in changes to this tradition. Given the national and international scope of climate change, the need for an integrated national strategy for controlling emissions and planning adaptation is strong. The Supreme Court should not create constitutional barriers to meeting this national need.

\section{B. The Preemptive Effect of a Federal Cap-and-Trade Scheme}

Assuming that Congress enacts fairly comprehensive climate change regulations, the continuing role of the states becomes an open question. That question may be settled without any need for considering constitutional issues.

212. The wetlands example also suggests another argument against limiting federal jurisdiction. The Court has cut back on federal jurisdiction, particularly as applied to "isolated" wetlands that lack a clear nexus to navigable waters. Climate change will profoundly reshape the nation's wetlands. Rising sea levels will impact coastal wetlands, while inland wetlands will be impacted by precipitation and temperature changes. The ecological functions of wetlands will be dislocated across the nation. All of this is part of a global phenomenon, and it seems a bit inane to say that some of the wetland impacts are purely the concern of local governments while others fall within national jurisdiction. Global climate change does not respect these boundaries.

213. Federal climate regulation might also be upheld, even if it went beyond the limits of the commerce power, if it were required by an international treaty. See Missouri v. Holland, 252 U.S. 416, 435 (1920). 
Perhaps states and localities will lose interest in climate change or will be content to assume whatever responsibilities Congress delegates to them without going further. Or perhaps Congress will settle the matter with either clear preemption language or strong savings clauses. Assuming that states remain active and that Congress does not speak clearly to the question, however, dormant Commerce Clause and preemption issues are likely to arise. How should courts approach them?

Some of the potential problems are illustrated by Clean Air Markets Group v. Pataki, ${ }^{214}$ which involved sulfur dioxide $\left(\mathrm{SO}_{2}\right)$ rather than GHGs. The issue in Clean Air Markets was whether a New York law was preempted because it undermined the cap-and-trade system for $\mathrm{SO}_{2}$ established by Congress. ${ }^{215}$ New York is a recipient of $\mathrm{SO}_{2}$ deposition from upwind states (mostly midwestern) in the form of acid rain. ${ }^{216} \mathrm{In}$ an effort to reduce $\mathrm{SO}_{2}$ emissions, the state required that New York utilities attach a restrictive covenant to any $\mathrm{SO}_{2}$ allowances they sell, which prohibits subsequent transfer to any of the upwind states. ${ }^{217}$ The state PUC also assessed "an air pollution mitigation offset" upon any New York utility whose allowances are sold or traded to an upwind state. The allowance equaled the sales price, so that in effect the sales price was confiscated by the state. ${ }^{218}$ Not surprisingly, the court held that the New York statute was preempted. ${ }^{219}$ The court pointed out that, "[a]though [it] does not technically limit the authority of New York utilities to transfer their allowances, it clearly interferes with their ability to effectuate such transfers. ${ }^{, 220}$ Allowing states to require restrictive covenants on transfer would obviously burden the interstate market. Although the Second Circuit did not find it necessary to reach the issue, the district court also held that the statute violated the dormant Commerce Clause. ${ }^{221}$ In the court's view, the statute was designed to interfere with the interstate market in pollution allowances and was therefore impermissibly protectionist. ${ }^{222}$

214. 338 F.3d 82 (2d Cir. 2003).

215. Id. at 83-84.

216. Id. at 84 .

217. Id.

218. Id. (quoting N.Y. PUB. SERV. LAW § 66-k(2) (McKinney 2000)).

219. Id. at 89 .

220. Id. at 88.

221. Clean Air Markets Group v. Pataki, 194 F. Supp. 2d 147 (N.D.N.Y. 2002).

222. As the district court put it,

Defendants argue that the statute is not protectionist because it burdens in-state units (with lower value allowances resulting from the restrictive covenant) rather than out-of-state interests. Defendants contend that the statute cannot be protectionist because it is aimed at protecting natural resources, not protecting in-state businesses. These arguments miss the point. Protectionism is about a state isolating itself from a common problem by restricting the movement of articles of commerce in interstate commerce. [citing Philadelphia v. New Jersey, 437 U.S. 617, 627-28 (1978)]. Here, the common problem is costeffectively meeting reduced $\mathrm{SO}_{2}$ emissions requirements to reduce acid deposition. The Congress determined that a way of helping electric utilities across the country approach the problem was to establish a 
The extent to which preemption poses a threat to state regulators depends in part on the type of regulation. Assume that the federal government has adopted a trading scheme, augmented by new product efficiency standards. In terms of the new product standards, Congress is likely to address preemption directly, either by continuing existing standards as discussed earlier, ${ }^{223}$ or by providing alternative language addressing preemption. These cases will present mundane issues of statutory interpretation.

Similarly, if Congress establishes a trading system, states may also regulate activities that are outside of the trading system completely-for example, by imposing green building standards or requiring new development to be accessible to public transportation. These kinds of traditionally local regulations should pose no constitutional problems. One might argue that Congress made a deliberate decision not to include such activities within the trading/offset system, but there are many reasons to exclude an activity-such as difficulties of monitoring and enforcement. Hence, there is no reason to infer an affirmative congressional decision that activities outside of the system should be left unregulated.

In considering the preemptive effect of a cap-and-trade scheme, we can divide state regulations into four groups. The first consists of regulations that have no connection whatsoever to the scheme. As we have just seen, these should be immune from preemption absent clear express preemption by Congress. The second group involves state regulation of activities that could be used as the basis for offsets by firms that are within the cap-and-trade scheme. The third group involves state regulation of activities that are themselves subject to the trading scheme, but where the state does not attempt to regulate the trade themselves. The fourth group consists of state efforts to limit trading by in-state entities. In general, the preemption becomes stronger as we move through the list, with the fourth category the most vulnerable to challenge.

We can begin analysis of cap-and-trade preemption by considering the second category - state regulation of activities that are not themselves covered by the trading scheme but are available as potential offsets by entities covered by the scheme. For example, a trading scheme for power companies might allow the companies to offset their emissions by planting trees, which absorb carbon from the atmosphere. States might create other kinds of regulations to mandate planting trees or to preserve existing forests. A company might claim that a state law mandating tree planting would interfere with the free market in such offsets,

nationwide system of trading $\mathrm{SO}_{2}$ allowances, in the fashion of a commodities market. As the New York legislature recognized, allowance trading can decrease the cost of reducing $\mathrm{SO}_{2}$ emissions. What New York has done with the Air Pollution Mitigation Law is to deem itself most affected by acid deposition and place restrictions on the trade of $\mathrm{SO}_{2}$ allowances to states it finds to be the highest sources of acid deposition within its borders. This it cannot do.

Id. at 160. The court also found that in any event the New York law would fail the balancing test, since it burdened commerce without producing any significant benefit to the state (because midwestern utilities had unused allowances of their own). Id. at 162-63.

223. See supra text accompanying notes $36-37,52-53$. 
because once an area is planted with trees it is no longer part of the supply of potential unused offset sites.

These category-two regulations should withstand preemption challenge. For one thing, the offset scheme is likely to allow the use of offsets only for activities that are not otherwise legally mandated, because otherwise the offsets would not be procuring real reductions. In effect, the offset rules are likely to defer to state regulation. Moreover, it would be difficult to apply preemption to all state regulations that might decrease the level of every activity that might generate an offset, so considerations of workability argue against finding preemption. For example, if planting trees would qualify as an offset, every municipal decision to permit a parking lot would be in effect reducing the amount of land available for offsets, and it would be bizarre to think that Congress meant to preempt all such actions.

More general considerations support the validity of category-two state regulations of potential offset activities. Presumably, the main purpose of the capand-trade scheme is to reduce emissions from the industry itself, rather than coerce the industry into bribing others to reduce their emissions. Offsets broaden the scope of the scheme, but regulators probably expect them to have only a secondary impact rather than displacing the incentive provided by the scheme for the industry to reduce its own emissions. Thus, the cost of obtaining offsets should have a secondary effect on allowance prices rather than being the main driver of allowance supply. Moreover, even if the offset rules fail to explicitly require that the offset activity be additive rather than otherwise mandated by law, the general purpose of offsets is consistent with state regulation-the point of the offset activity is to obtain new reductions in emissions from other sources, rather than give the industry credit for reductions that would have happened otherwise. Thus, state laws restricting activities that might otherwise be the subjects of offsets should not interfere with the goals of the trading scheme in a significant way. Assuming that the state restrictions are nondiscriminatory, the restrictions should also survive a balancing analysis under the dormant Commerce Clause, given the state's substantial interest in reducing emissions and the modest impact on the availability of offsets to interstate purchasers.

A more difficult question is posed by the third type of regulation, where the states regulate the very activity that is the subject of trading. For example, suppose that Congress establishes a national $\mathrm{CO}_{2}$ trading system for electrical generators but that a state prohibits its utilities from entering into long-term supply contracts with high emitters, perhaps coupled with direct emissions limitations on in-state generators. ${ }^{224}$ Also assume that the federal statute says nothing directly about preemption, and that in turn, the state law does not restrict allowance trading. Utilities with high levels of emissions will presumably attack the state prohibition under Clean Air Markets. The Second Circuit's decision seems distinguishable because the court emphasized how directly the state was seeking to intervene in the interstate market. Certainly, the Second Circuit did not indicate that all state regulations of $\mathrm{SO}_{2}$ emissions were prohibited; the regulatory scheme

224. Compare the California regulations discussed supra text accompanying notes $40-48$ 
before the court interfered with the trading system far more directly by banning certain sales within the system and encumbering allowances with restrictive covenants. Clean Air Markets does pose a threat if the state requires reductions in emissions but then tries to prevent sources from selling the allowances that they no longer need because of the reductions. But it seems irrelevant in cases where the emission reduction would not free up an allowance ${ }^{225}$ or where it does free an allowance that the state allows to be sold.

It might seem pointless for a state to mandate reductions without also banning sale of the allowances that are freed up. To the extent that state regulation merely results in shifting allowances between generators, it does not affect the total amount of emissions nationally. A state might nevertheless want to mandate the lower emission levels in order to achieve long-term goals. As with the current California utility regulations, one goal might include pressing sources used by local customers to accelerate their achievement of lower emissions in order to avoid price uncertainty later. The state might also want to encourage the development of new technology.

Regulations of this kind should not pose a preemption problem. The regulations do shift the pattern of allowance purchases and sales, but do not affect the achievement of the national cap. Inevitably, when a state reduces some form of consumption, it lowers demand in the national market (even if only slightly), thereby decreasing production levels but shifting consumption to other states. This is a normal and innocuous effect of state regulation. The best argument against the validity of the scheme would be that the trading scheme was not only supposed to create incentives but to free industry to attain the national goals however it chose. Yet this policy of unfettered industry decision-making is not necessarily inherent in the use of a cap-and-trade scheme. Moreover, there would again be workability issues in applying preemption. States might regulate sources in many ways that would result in lower greenhouse emissions-for example, particulate regulations might push electrical generators into switching from coal to natural gas, resulting in lower emissions. It seems unlikely that Congress would want to prohibit all such state regulations given its clear desire to allow states to exceed national standards in regulating conventional pollutants.

The real problem, however, is that state regulations of this kind will have limited ability to address climate change. A state's actions by themselves will not affect national $\mathrm{CO}_{2}$ emissions because reducing sources of emissions in that state simply frees up allowances that other generators can use. Thus, a state's restrictions will only be effective in reducing national emissions if the state can prohibit sources from trading the resulting allowances. Thus, states will be tempted to move into the fourth category of regulations, not only regulating covered activities but banning the sale of the resulting offsets. Congress might in fact want to prohibit generators from trading allowances that have been freed up because of

225. This might be the case with renewable portfolio standards if the standards apply to entities that are not themselves inside the trading scheme-for instance, the RPS applied to a retail utility while the trading scheme applied to generating companies. See Neal J. Cabral, The Role of Renewable Portfolio Standards in the Context of a National Carbon Cap-and-Trade Program, 8 SustaINABLE DEV. L. \& POL'Y 13 (2007). 
legal restrictions imposed by state law. If Congress does not do so, however, there seems to be a strong argument for preemption in the absence of an applicable savings clause. ${ }^{226}$ Thus, states may wish to restrict themselves to activities in the second category by adopting restrictions on in-state utilities, even without the ability to block trades, either because of concerns about future regulatory changes (for example, a lowering of the federal cap) that might impact prices and supplies for its consumers, or simply in the hopes of forcing improvements in technology. ${ }^{227}$

It may be helpful to provide a summary of the preceding discussion:

Table 1: Preemption of State Regulations by Federal Cap-and-Trade Legislation

\begin{tabular}{|l|l|l|l|}
\hline $\begin{array}{l}\text { Type of } \\
\text { regulation }\end{array}$ & Definition & $\begin{array}{l}\text { Preemption } \\
\text { Outcome }\end{array}$ \\
\hline $\begin{array}{l}\text { Category } \\
1\end{array}$ & $\begin{array}{l}\text { State regulation of activities } \\
\text { that do not require } \\
\text { allowances and do not } \\
\text { qualify as offsets }\end{array}$ & $\begin{array}{l}\text { State zoning to } \\
\text { encourage } \\
\text { public } \\
\text { transportation } \\
\text { or reduce } \\
\text { automobile use }\end{array}$ & $\begin{array}{l}\text { Not preempted } \\
\text { absent clear express } \\
\text { statutory language }\end{array}$ \\
\hline $\begin{array}{l}\text { Category } \\
2\end{array}$ & $\begin{array}{l}\text { State regulation of activities } \\
\text { that qualify as offsets }\end{array}$ & $\begin{array}{l}\text { State mandates } \\
\text { to plant trees }\end{array}$ & $\begin{array}{l}\text { Not preempted } \\
\text { absent clear express } \\
\text { statutory language }\end{array}$ \\
\hline $\begin{array}{l}\text { Category } \\
3\end{array}$ & $\begin{array}{l}\text { State regulation of activities } \\
\text { that require federal } \\
\text { allowance, but no state } \\
\text { effort to regulate allowance } \\
\text { transactions }\end{array}$ & $\begin{array}{l}\text { Renewable } \\
\text { energy } \\
\text { portfolios }\end{array}$ & $\begin{array}{l}\text { Not preempted } \\
\text { absent express } \\
\text { statutory language } \\
\text { or direct effect on } \\
\text { federal trading } \\
\text { scheme }\end{array}$ \\
\hline $\begin{array}{l}\text { Category } \\
4\end{array}$ & $\begin{array}{l}\text { State restrictions on } \\
\text { allowance transactions by } \\
\text { in-state firms as an adjunct } \\
\text { to state regulation of the } \\
\text { emissions of those firms }\end{array}$ & $\begin{array}{l}\text { Ban on sale of } \\
\text { allowances } \\
\text { compliance } \\
\text { with state rules }\end{array}$ & $\begin{array}{l}\text { Preempted in the } \\
\text { absence of clear } \\
\text { savings clause }\end{array}$ \\
\hline
\end{tabular}

226. Preemption of efforts to block interstate allowance sales is supported by the Second Circuit's Pataki ruling and by commentators. See Clean Air Markets Group v. Pataki, 338 F.3d 82 (2d Cir. 2003); Robert L. Glicksman \& Richard E. Levy, A Collective Action Perspective on Ceiling Preemption by Federal Environmental Regulation: The Case of Global Climate Change, 102 Nw. U. L. REV. 579, 644-45 (2008).

227. Arguably, a state would not need to resort to measures directly addressing GHG emissions by generators. Instead, it could impose more stringent limitations on total emissions of conventional pollutants per hour generated. Such restrictions would inevitably favor plants that had high fuel efficiency or used renewable energy sources. 
Regardless of which of the four classes of regulation is involved, sources may well argue that any congressional cap-and-trade scheme is meant to be comprehensive and hence to preempt the field of climate change regulation. This argument may be superficially appealing but should be rejected. There are other plausible explanations for why congressional regulations stop where they do, without necessarily indicating a desire to eliminate all regulation beyond those limits by states. First, the limits of a trading system may involve other kinds of policy determinations. The limited scope or requirements of a federal trading scheme may involve practical determinations that other activities are not suitable for inclusion because of difficulties of monitoring or enforcement. Similarly, Congress might have feared that a lower cap would have undue national economic consequences, but state activities that do not in effect lower the national cap do not pose this concern even if they lower emissions in a particular state. Second, the limitations of the scheme may reflect a compromise, and this compromise may well be that the federal scheme should cover only certain matters but leave others open to state regulation. Without some clear indication that Congress intended to resolve all possible claims between stakeholders in climate change regulation by setting the limits of regulation by all levels of government, there is no reason to infer such a global settlement of all climate regulation issues.

\section{The Public Policy Argument for a Presumption in Favor of State Climate Regulation}

Attempting to eliminate all state regulation of climate change is likely to be futile. It seems inevitable that states will play a role in climate mitigation, either because they can regulate activities that are outside of whatever scheme Congress employs or because Congress will enlist them in implementation of federal goals, as it has under the Clean Air Act already. There are strong arguments that state regulations should generally survive constitutional challenge, except where states attempt to prohibit participation in federally sanctioned markets or discriminate against out-of-state emitters.

There is considerable controversy over whether, in general, there should be a presumption against preemption. ${ }^{228}$ In the case of climate change, at least, there are strong pragmatic arguments that reinforce the usual federalism-based contentions. First, climate change involves an enormous collective action problem, since solving it will involve the combined activities of every major economy in the world. It is a truism that public goods tend to be undersupplied, and climate is the most public of all public goods. Thus, we should embrace climate actions by whoever undertakes them, for it is more likely that the actions will be too little than that they will be too much.

Second, climate change also involves another major externality, with the activities of the current generation potentially imposing massive costs on future

228. For a review of the contending arguments, see Note, New Evidence on the Presumption Against Preemption: An Empirical Study of Congressional Responses to Supreme Court Preemption Decisions, 120 HARV. L. REV. 1604, 1607-11 (2007). See also Cipollone v. Liggett Group, Inc., 505 U.S. 504, 518 (calling for judges to give express preemption clauses a narrow reading). 
generations. Again, the odds are that regulation will be too timid because it will reflect the interests of current generations rather than the later generations who today's society may be harming. Perhaps more significantly, this also means that many of those who will be most affected have no voice in today's political process. They are the most underrepresented of all underrepresented groups-not only do they have no vote, but they have no capacity to speak for themselves. Courts have often acted to protect underrepresented groups, ${ }^{229}$ and some canons of interpretation seem designed for this purpose. ${ }^{230} \mathrm{~A}$ presumption against preemption of state climate regulation would fit within this tradition.

The argument against preemption may also gather some strength from the lesser known provisions of the National Environmental Policy Act of 1969 (NEPA), the statute which mandates environmental impact statements. ${ }^{231}$ Although the statute is best known for that mandate, it also contains other provisions, including a broad statement of environmental policy. ${ }^{232}$ NEPA calls on the government to use "all practicable means, consistent with other essential considerations of national policy" to achieve a list of environmental goals. ${ }^{233}$ These goals include directives to "fulfill the responsibilities of each generation as trustee of the environment for succeeding generations," and to "assure for all Americans safe, healthful, productive, and esthetically and culturally pleasing surroundings." ${ }^{234}$ The statute also declares the "critical importance of restoring and maintaining environmental quality to the overall welfare and development of man . ..."235 The Supreme Court has ruled that a court has no power to review whether a particular agency action comports with these policies, assuming a valid impact statement exists. ${ }^{236}$ Nevertheless, Congress evidently intended these policies to guide the development of federal law. In section 102(1) of NEPA, Congress directed that "to the fullest extent possible" the "policies, regulations, and public laws of the United States shall be interpreted and administered in accordance with the policies set forth in this chapter.,237

In many ways, NEPA was ahead of its time in laying out a general approach to environmental issues. Section 101(a) declares that "it is the continuing policy of the Federal Government, in cooperation with State and local governments . . . to use all practicable means and measures ... [to] fulfill the social, economic, and other requirements of present and future generations of Americans." ${ }^{238}$ In a similar vein, section 101(b) makes it the continuing

229. See generally JOHN HART ELY, DEMOCRACY AND DISTRUST: A THEORY OF JUDICIAL REVIEW (1980).

230. For example, the canon requiring interpretation of ambiguous treaties and federal statutes in favor of Indian tribes.

231. National Environmental Policy Act of 1969, Pub. L. No. 91-190, 83 Stat. 852 (codified as amended at 42 U.S.C. $\S \S 4321-47$ ) (2006) [hereinafter NEPA].

232. Id.

233. NEPA § $101($ b), 42 U.S.C. $\S 4331($ b).

234. NEPA $\S 101(b), 42$ U.S.C. $\$ 4331(b)(1)-(2)$.

235. NEPA § 101(a), 42 U.S.C. $\S 4331$ (a).

236. Robertson v. Methow Valley Citizens Council, 490 U.S. 332 (1989).

237. NEPA $\S 102(1), 42$ U.S.C. $\S 4332$.

238. NEPA $\S 101$ (a), 42 U.S.C. $\S 4331$ (a) (emphasis added). 
responsibility of the federal government "to use all practicable means, consistent with other essential considerations of national policy, to improve and coordinate Federal plans, functions, programs, and resources to the end that the Nation may-(1) fulfill the responsibilities of each generation as trustee of the environment for succeeding generations ...."239

Putting these directives together with section 102(1)'s mandate, a presumption against climate preemption would not be difficult to defend even on formalist grounds, simply as a matter of applying NEPA. It is true that the Court has dismissed the enforceability of this language, but it is hard to see how such a result could be justified by a court that truly cared about statutory language. In any event, NEPA's policy pronouncements at least give official public recognition to these central policy concerns, making it more difficult to dismiss them as irrelevant to judicial doctrine. Moreover, NEPA's invocation of the rights of future generations reinforces the normative argument that courts should, in doubtful cases, weigh in on behalf of the interests of those generations by encouraging climate initiatives at every level of government. In addition, we should also consider other benefits of state initiatives in the field of climate change, such as the possibility that the states could act as laboratories to test new policies to address this novel problem. ${ }^{240}$

Of course, there may be good reasons to limit state regulation of some particular aspects of climate change, such as the costs of non uniform regulation or the exigencies of international negotiations. But courts are likely to be in a poor position to identify these problems or to balance them against the benefits of state regulation. Congress should be left with the primary responsibility for carving out exceptions from the otherwise broad sweep of state regulatory authority. It is likely that the first round of federal legislation on climate change will not be the last, for this is a problem that will be with us for decades if not generations, and the first

\section{NEPA § $101(\mathrm{~b}), 42$ U.S.C. $\S 4331$ (b)-(b)(1).}

240. The role of the states as innovators is stressed in Alexandra B. Klass, State Innovation and Preemption: Lessons from Environmental Law, LOY. L.A. L. REV. (forthcoming 2008), available at http://ssrn.com/abstract=1093307. A broader argument has also been made that federal statutes should not be construed to set ceilings and thereby eliminate more stringent state regulation:

Principled rationales exist to distinguish and embrace a protective federal one-way ratchet of floor preemption, or at least to see floor preemption as less institutionally problematic than the new breed of ceiling preemption that this Article refers to as "unitary federal choice preemption." Unitary federal choice preemption, by definition, precludes additional state and local protections and eliminates institutional diversity that is preserved (though limited) by floor preemption. Unitary federal choice preemption is, upon closer examination, a regulatory choice that in operation runs counter to many of the most valuable elements of federalist schemes. In contrast, federal floors retain the benefits of multiple regulatory voices, protections, and diverse regulatory modalities. These factors serve as important antidotes to common forms of regulatory dysfunction.

William W. Buzbee, Asymmetrical Regulation: Risk, Preemption, and the Floor/Ceiling Distinction, 82 N.Y.U. L. REv. 1547, 1555 (2007). 
round of regulatory efforts are unlikely to be the perfect solution. It is not unreasonable to expect Congress to address any over-reaching by states in the course of this ongoing legislative process.

Given that the political system is likely to undersupply climate regulation, courts should be inclined to provide a friendly reception to any and all climate regulation, rather than subjecting it to skeptical scrutiny. Moreover, courts are likely to find it difficult to apply undue burden tests or implied preemption doctrines in this area. Courts can fairly easily weed out the most dubious forms of state regulation, involving discrimination against out-of-state firms or direct contradiction of federal law. But they are poorly situated to deal with the remaining, more debatable instances of state regulation, and they should leave it to Congress to balance the virtues of state regulation against any indirect interference with national interests.

\section{CONCLUSION}

Science has shown us just how tightly small-scale happenings are coupled with large-scale happenings. Climate is affected by millions of small-scale decisions about what appliances to use, what car to drive, how often to drive, and where to live, as well as by the decisions of major corporations about energy investments. In turn, climate will have effects on all of these decisions. Thus, we cannot properly say that climate change is either a purely local or a global affairit involves the very local as well as the completely global.

As we have seen, current law interdicts certain kinds of state regulations but leaves the bulk of state regulation subject to judicial overview under vague standards of "undue burden" or posing an "obstacle" to federal law. Massachusetts v. EPA does not speak directly to this issue, but contains some cautions against unduly minimizing the interests of the states in the area of climate change. If nothing else, Massachusetts v. EPA makes it clear that climate change is very much the legitimate concern of state governments, rather than being exclusively in the national or international domain.

There are other cogent reasons why state climate regulations should enjoy a clear presumption of validity. Under-regulation is a greater risk than overregulation in the climate area, given the huge collective action problem in addressing the climate issue and the fact that some of the primary stakeholders are future generations who have no political voice. Moreover, the federal government's general environmental policy, as enunciated in sometimes forgotten but still-valid provisions of NEPA, clearly favors federal-state cooperation and respect for the interests of later generations. Congress will probably be engaged in an on-going process of legislation regarding climate, and any over-reaching by states can best be addressed legislatively.

Given this presumption of validity, in the absence of clear preemptive language, a federal cap-and-trade scheme should have only limited preemptive effect. It should not affect state regulation of activities that are not related to the trading system or of activities that might be potential offsets. As to state regulations of activities that generate or require allowances, preemption should only be triggered if the state attempts to ban or otherwise limit the purchase or sale 
of allowances. Congress can provide a broader scope of preemption if it so desires, but there is little reason for courts to impose preemption when Congress has failed to make clear its intention to do so.

Climate change poses formidable challenges to our governance system. It assigns, informally if not constitutionally, some matters to local authorities and others to the federal government. Responses to climate change, both in terms of mitigation and adaptation, will cut across these lines. Our society will have to be creative in responding and remolding familiar doctrines where necessary to allow us to respond to the realities of the situation. It may seem unfamiliar and strange for states to regulate an issue that has such global repercussions as climate change. Yet, as Justice Brandeis said in his famous dissent in New State Ice Co. v. Liebmann, ${ }^{241}$ a decision involving the permissible scope of state regulation: "[i]f we would guide by the light of reason, we must let our minds be bold.,"242

241. 285 U.S. 262, 280 (1932) (Brandeis, J., dissenting).

242. Id. at 311 . 